\title{
Organic Anions Facilitate the Mobilization of Soil Organic Phosphorus and Enhances Its Subsequent Lability To Phosphatases
}

\author{
Alan E. Richardson ( $\nabla$ alan.richardson@csiro.au ) \\ CSIRO Agriculture \& Food https://orcid.org/0000-0003-0708-1299 \\ Timothy George \\ James Hutton Institute, Ecological Sciences \\ Maarten Hens \\ NBO, Research Institute for Nature and Forest \\ Emmanuel Delhaize \\ CSIRO Agriculture \& Food \\ Peter Ryan \\ CSIRO Agriculture \& Food \\ Richard Simpson \\ CSIRO Agriculture \& Food \\ Peter Hocking \\ CSIRO Agriculture \& Food
}

\section{Research Article}

Keywords: NMR, plant nutrition, citrate, malate, oxalate, phytate, phytase

Posted Date: January 20th, 2022

DOI: https://doi.org/10.21203/rs.3.rs-1212066/v1

License: (c) (i) This work is licensed under a Creative Commons Attribution 4.0 International License. Read Full License

Version of Record: A version of this preprint was published at Plant and Soil on April 18th, 2022. See the published version at https://doi.org/10.1007/s11104-022-05405-5. 


\section{Abstract \\ Purpose}

Organic anions commonly released from plant roots are widely reported to mobilize soil phosphorus $(P)$. We characterized soil organic $\mathrm{P}$ that was mobilized by organic anions and assessed its amenability to hydrolysis by phosphatase enzymes.

\section{Methods}

Six soils differing in organic $\mathrm{P}$ content were extracted with citrate, malate or oxalate solutions and incubated with preparations of phosphomonoesterase, phosphodiesterase, or phytase. Organic $\mathrm{P}$ compounds present in these extracts were putatively identified and quantified with solution ${ }^{31} \mathrm{P}$ NMR spectroscopy and the enzyme-labile $P$ fractions were assessed by changes in molybdate reactive $\mathrm{P}(\mathrm{MRP})$ concentration.

\section{Results}

Organic P mobilization varied markedly among the organic anions. Extraction with $10 \mathrm{mM}$ citrate was most effective and extracted 7.8-fold more total $P$ than the water controls across all soils. Approximately $95 \%$ of the extracted $P$ was non-MRP. The organic anions increased both the amount of $\mathrm{P}$ extracted and the proportion of the total extracted $\mathrm{P}$ that was phosphatase labile. Phytase was generally the most effective enzyme with up to $60 \%$ of the total non-MRP being amenable to hydrolysis by phytase across all extracts. The presence of inositol hexakisphosphates in the extracts, as

well as other forms of organic $\mathrm{P}$ including nucleic acids and phospholipids, was verified by ${ }^{31} \mathrm{P}$ NMR with concentrations dependent on both organic anion and soil type.

\section{Conclusion}

The combination of organic anions and phosphatases represents a key mechanism by which plants and microorganisms can enhance the bioavailability of soil P. This has important implications for understanding $P$ dynamics in natural and managed ecosystems and for ongoing efforts to improve the P-use efficiency of agricultural plants.

\section{Introduction}

Phosphorus $(P)$ is essential for plant growth and function and is often present in soils at concentrations that are deficient for plant growth. Not only is $\mathrm{P}$ important for driving plant productivity and plant diversity in natural systems (Lambers et al. 2015; Turner et al. 2018; Wassen et al. 2005; Zemunik et al, 2015), it is often a limiting nutrient for productivity in many managed agricultural systems. This is particularly true for the ancient and highly weathered soils in Australia, which are among the most naturally P-deficient in the world. The adaptation of plants to soils with low levels of plant-available $P$ has been studied extensively across a wide range of ecosystems. Indeed, research conducted in the Lambers' laboratory at the University of Western Australia has been instrumental in helping to understand how native plants and crops adapt and respond to P-limited environments, and especially the role of root exudates in mobilizing soil P (Lambers et al. 2002; Lambers et al. 2008; Lambers et al. 2011; Lambers et al. 2015). The pivotal articles and reviews published in Plant and Soil, including many by Lambers and his team, have revealed much about 
the chemistry of soil P (McLaughlin et al. 2011; Weaver and Wong 2011) and led to potential strategies for managing fertilizer use in agriculture (Richardson et al. 2011a; Simpson et al. 2011; Mclvor et al. 2011).

In addition to the physiological and morphological changes to roots (Lynch and Brown 2001; Richardson et al. 2009), P deficiency is often associated with an increased release of organic anions (also referred to as carboxylates) from roots into the rhizosphere. Organic anions increase the availability of $\mathrm{P}$ in soil for plant uptake, especially under conditions of $P$ deficiency. The increased rates of organic anion release in response to $P$ deficiency have been described in many native Australian plant species that develop cluster roots (e.g., the Proteacea: Roelofs et al. 2001; Lambers et al. 2002; Lambers et al. 2015) as well as in a wide range of agricultural species with and without cluster roots, including pasture legumes and grasses, grain legumes and cereals (Nuruzzaman et al. 2006; Pearse et al. 2006; Wang et al. 2013; Wouterlood et al. 2004; Kidd et al. 2018). The release of citrate and malate from the specialized cluster roots of white lupin (Lupinus albus L.) has been studied in greatest detail (e.g., Veneklass et al. 2003; Shane et al. 2008; Wang et al, 2013). In this species, citrate concentrations of 5 to $50 \mu \mathrm{mol} \mathrm{g}{ }^{-1}$ soil (corresponding to expected soil solution concentrations of 1 to $10 \mathrm{mM}$ ) have been reported around the cluster roots (Dinkelaker et al 1989; Gerke et al. 1994).

Various studies using soil-grown plants have shown that organic anions released from roots can increase the concentration of the plant-available P (as orthophosphate) in the soil solution and many examples (e.g., as outlined in references above) have been reported. The effectiveness of different organic anions in mobilizing $P$, however, is highly dependent on soil type and the form of $P$ either present in soil or provided to the plants. Plant species and genotype is also important because it determines the type and amount of each organic anion released and the dynamics of that release (Wang and Lambers 2020). More direct examples of P mobilization by organic anions have extracted soils in vitro with different organic anion solutions (Khademi et al. 2009; Ryan et al. 2014). For example, using seven contrasting Australian soils differing in pH and P content, Ryan et al. (2014) showed that both $1 \mathrm{mM}$ and $10 \mathrm{mM}$ citrate increased the concentration of orthophosphate, with greater mobilization occurring in acidic soils than for alkalinecalcareous soils. Citrate was able to mobilize $P$ from both the inorganic and organic $P$ fractions and this varied markedly between soils. Organic anions are proposed to mobilize P from sparingly-available pools of soil P through a number of processes including: (i) competition for sorption sites (i.e., desorption of orthophosphate), (ii) ligandpromoted mineral dissolution or exchange reactions with cations of iron $\left(\mathrm{Fe}^{2+/ 3+}\right)$, aluminum $\left(\mathrm{Al}^{3+}\right)$ or calcium $\left(\mathrm{Ca}^{2+}\right)$, or (iii) interactions with soil microorganisms. For the latter process, microorganisms may directly release organic anions themselves, or mobilize P by promoting root growth or through biomass turnover (Richardson et al. 2011a; Richardson et al. 20011b; Wang and Lambers, 2020). Organic anion release is also commonly associated with release of protons $\left(\mathrm{H}^{+}\right)$which can induce local regions of acidification that further influence the desorption and diffusion of $\mathrm{P}$ in soil (Barrow et al. 2017). Local acidification may also promote the solubilization of precipitated pools of Ca-P prevalent in alkaline soils (Jones 1998).

Organic $\mathrm{P}$ in soil typically accounts for at least $50 \%$ of the total soil $\mathrm{P}$ and forms of organic $\mathrm{P}$ can be identified and quantified using solution ${ }^{31} \mathrm{P}$ NMR spectroscopy (Turner et al. 2002; McLaren et al. 2019a). Most of the organic $P$ in soil occurs as phosphomonoesters (e.g., inositol hexakisphosphates, lower order inositol phosphates and other sugarphosphates), phosphodiesters (e.g., phospholipids and nucleic acids, primarily as DNA) and a large pool of poorly characterized monoester compounds (McLaren et al. 2019a). Of these, the myo and scyllo stereoisomers of inositol hexakisphosphate are the most prevalent in many soils (Turner 2007). Similar to orthophosphate anions, inositol hexakisphosphates are readily adsorbed in soils and can also be precipitated with $\mathrm{Al}^{3+}, \mathrm{Fe}^{2+/ 3+}$ and $\mathrm{Ca}^{2+}$ (Celi and Barberis 2005; Jackman and Black 1951; Tang et al. 2006). Inositol phosphates are furthermore complexed within high molecular weight soil organic matter as structurally complex, supra- and macro-molecular monoester material that otherwise remains poorly characterized (Hong and Yamane 1981; McLaren et al. 2019b). Whilst various studies have demonstrated that organic anion extractions can increase the concentration of organic P (Otani and Ae 1999; Hayes et

Page $3 / 25$ 
al. 2000; Wei et al. 2010, Ryan et al. 2014), the identity of the organic P compounds released and their contribution to plant nutrition remains to be further investigated (Richardson et al., 2005; George et al. 2018).

The nature of organic $\mathrm{P}$ in soil has been characterized by the lability of extracted $\mathrm{P}$ to dephosphorylation by various phosphatase enzymes, which show differing specificity toward mono-ester and di-ester forms of organic $\mathrm{P}$ (Hayes et al. 2000; Bünemann 2008; Darch et al. 2016; Jarosch et al. 2019). A meta-analysis by Bünemann (2008) showed that up to $60 \%$ of organic $P$ was typically amendable to dephosphorylation across a wide range of soil extracts and water samples, with phytases (i.e., inositol hexakisphosphate phosphohydrolyases) generally showing the greatest release of orthophosphate. Significantly, using two Australian pasture soils, Hayes et al. (2000) showed that up $40 \%$ of the total P extracted by $50 \mathrm{mM}$ citric acid was hydrolyzed by a highly purified phytase, whereas up to $79 \%$ was hydrolyzed by a commercially available phytase preparation that exhibited a wider substrate specificity. By contrast, lesser quantities of organic $\mathrm{P}(<17 \%$ and $<9 \%)$ were dephosphorylated by the commercial phytase in water and $0.5 \mathrm{M}$ sodium bicarbonate extracts, respectively, even though bicarbonate itself extracted three to four times more organic P (Hayes et al. 2000). This indicates a potentially strong interaction between organic anions in the mobilization of organic $\mathrm{P}$ substrates and their subsequent lability to phosphatases to release bioavailable P as orthophosphate.

In this study we sought to further investigate the interaction between organic anions and phosphatases in the mobilization of soil organic $\mathrm{P}$ and lability of the extracted $\mathrm{P}$ to dephosphorylation. We hypothesized that different combinations of organic anions and phosphatases would differentially influence $P$ mobilization across a range of contrasting soil types, and that that greater release of $\mathrm{P}$ would occur when specific combinations of organic anion and phosphatase were present as potential functional components of root exudates. To test these hypotheses, we used a range of citrate, malate and oxalate concentrations in combination with commercially available preparations of acidphosphomonoesterase (PME), phosphodiesterase (PDE) and phytase (PHY) to examine P release from six contrasting

agricultural soils. Solution ${ }^{31} \mathrm{P}$ NMR spectroscopy was used to identify and quantify the presence of phosphomonoester and phosphodiester forms of organic $\mathrm{P}$ directly in the extracts. Our findings demonstrate that organic anions both mobilize organic $P$ from soil and render it more labile to dephosphorylation by phosphatases. These results have important implications for the $P$ nutrition of plants and the dynamics of $P$ in soils.

\section{Materials And Methods}

\section{Soil characterization and analysis}

Diverse soils differing in total $P$ and organic $P$ content were collected from the 0 to $10 \mathrm{~cm}$ layer of the profile from six sites across central and southern News South Wales and the Australian Capital Territory in 2001 (Table 1). The soils were representative of pasture and crop systems and were classified according to the Australian classification system (Isbell 1996). Large organic matter fragments were first removed from the samples which were then thoroughly mixed, air dried and passed through a $2 \mathrm{~mm}$ sieve prior to storage. Subsamples were also pulverized with a puck mill (Labtechnics, Model LM1, Australia). 
Table 1

Classification and properties of soils $(0$ to $10 \mathrm{~cm})$ used in the study.

\begin{tabular}{|c|c|c|c|c|c|c|}
\hline Soil & Robertson & Grenfell & Wallaroo & Camden & Greenthrope & Berthong \\
\hline Location & $\begin{array}{l}\text { Southern } \\
\text { Highlands } \\
\text { NSW }\end{array}$ & $\begin{array}{l}\text { Central West } \\
\text { NSW }\end{array}$ & Hall ACT & Sydney NSW & $\begin{array}{l}\text { Central } \\
\text { West NSW }\end{array}$ & $\begin{array}{l}\text { Central West } \\
\text { NSW }\end{array}$ \\
\hline Soil type ${ }^{a}$ & $\begin{array}{l}\text { Red } \\
\text { Ferrosol }\end{array}$ & Brown Kandosol & $\begin{array}{l}\text { Yellow } \\
\text { Chromosol }\end{array}$ & $\begin{array}{l}\text { Black } \\
\text { Vertosol }\end{array}$ & $\begin{array}{l}\text { Brown } \\
\text { Kandosol }\end{array}$ & Red Kandosol \\
\hline Land-use & pasture & cropping & pasture & pasture & cropping & cropping \\
\hline $\begin{array}{l}\text { Soil pH } \\
\text { (water) }\end{array}$ & 5.58 & 5.37 & 5.59 & 5.61 & 6.03 & 6.25 \\
\hline $\begin{array}{l}\text { Soil pH } \\
\left(\mathrm{CaCl}_{2}\right)\end{array}$ & 4.90 & 4.41 & 4.42 & 4.87 & 5.42 & 5.58 \\
\hline $\begin{array}{l}\text { Organic } \\
\text { matter }^{b}(\%)\end{array}$ & 19.9 & nd & 5.7 & 9.2 & 3.3 & 6.8 \\
\hline $\begin{array}{l}\text { Total C }{ }^{c}(\% \\
\text { soil mass) }\end{array}$ & 5.98 & 2.03 & 1.73 & 3.49 & 1.12 & 2.28 \\
\hline $\begin{array}{l}\text { Total N c (\% } \\
\text { soil mass) }\end{array}$ & 0.54 & 0.17 & 0.14 & 0.31 & 0.10 & 0.19 \\
\hline $\begin{array}{l}\text { Total P d } \\
\left(\mathrm{mg} \mathrm{kg}^{-1}\right)\end{array}$ & $2664(22) e$ & $305(6)$ & $\begin{array}{l}375 \\
(12)\end{array}$ & $633(19)$ & $332(12)$ & $602(12)$ \\
\hline \multicolumn{7}{|l|}{$\begin{array}{l}\text { Total P } \\
\text { (ignition- } \\
\text { extraction) }\end{array}$} \\
\hline $\begin{array}{l}\text { Total P (mg } \\
\left.\mathrm{kg}^{-1}\right)\end{array}$ & $1540.6(11.7)$ & $175.2(0.4)$ & $\begin{array}{l}194.7 \\
(1.3)\end{array}$ & $557.0(2.5)$ & $238.1(1.3)$ & $407.5(3.2)$ \\
\hline $\begin{array}{l}\text { Inorganic } P \\
\left(\mathrm{mg} \mathrm{kg}^{-1}\right)\end{array}$ & $478.7(2.1)$ & $65.0(1.6)$ & $\begin{array}{l}68.7 \\
(1.8)\end{array}$ & $195.2(3.4)$ & $127.8(0.7)$ & $218.2(4.5)$ \\
\hline $\begin{array}{l}\text { Organic P } \\
(\%)\end{array}$ & 68.9 & 62.9 & 64.7 & 65.0 & 46.3 & 46.4 \\
\hline \multicolumn{7}{|l|}{$\begin{array}{l}\text { Available } P \\
\text { (extraction) }^{g}\end{array}$} \\
\hline $\begin{array}{l}\text { Total P (mg } \\
\left.\mathrm{kg}^{-1}\right)\end{array}$ & $36.8(0.8)$ & $31.4(0.9)$ & $\begin{array}{l}23.3 \\
(0.2)\end{array}$ & $42.7(0.6)$ & $27.1(0.7)$ & $35.1(0.5)$ \\
\hline $\begin{array}{l}\text { Inorganic } P \\
\left(\mathrm{mg} \mathrm{kg}^{-1}\right)\end{array}$ & $6.3(0.1)$ & $6.6(0.1)$ & $\begin{array}{l}3.4 \\
(0.1)\end{array}$ & $11.0(0.3)$ & $15.3(0.2)$ & $20.1(0.3)$ \\
\hline $\begin{array}{l}\text { Organic P } \\
(\%)\end{array}$ & 82.9 & 79.0 & 85.4 & 74.2 & 43.5 & 42.7 \\
\hline
\end{tabular}

a Based on Australian Soil Classification system (Isbell, 1996).

${ }^{b}$ Organic matter estimated by loss of ignition ( $\mathrm{nd}=$ not determined). 


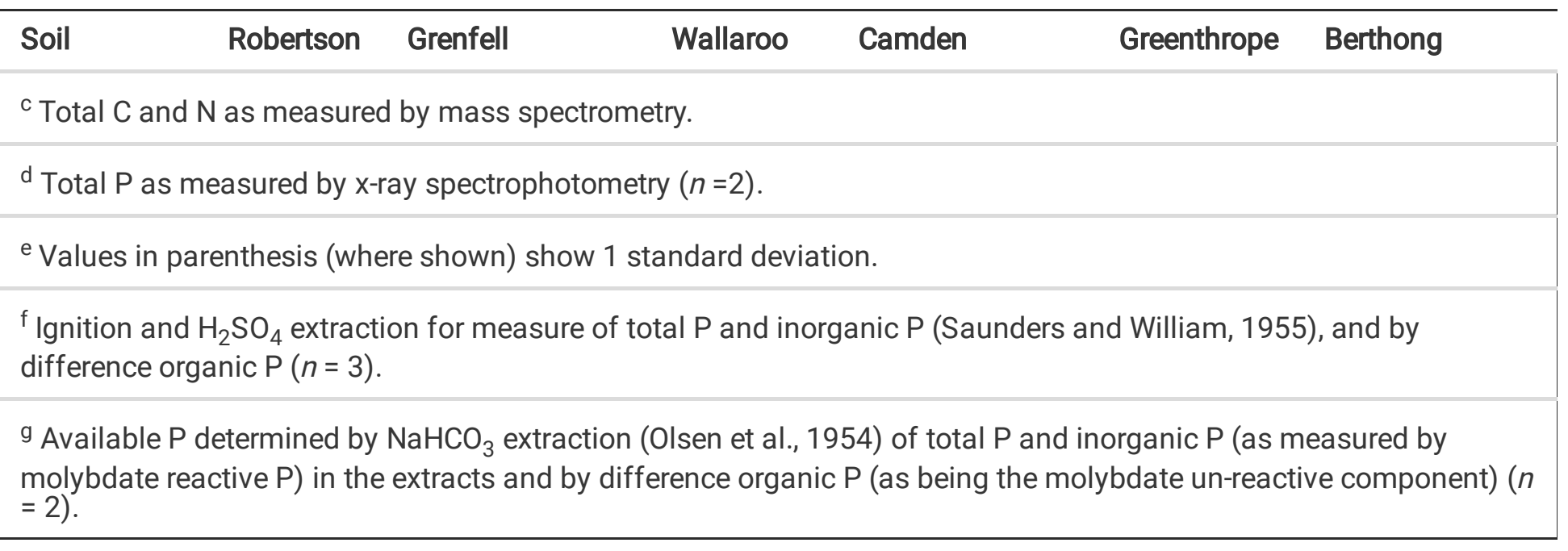

Samples of sieved soil were analyzed for $\mathrm{pH}$ in water and in $0.01 \mathrm{M} \mathrm{CaCl}_{2}$ using a 1:5 soil to solution suspension (Rayment and Lyons 2011). Loss on ignition (LOI) as an indicator of organic matter content was determined on milled samples by loss of mass from whole soil after drying the soils at $105^{\circ} \mathrm{C}$ and then ignition in a muffle furnace at $550^{\circ} \mathrm{C}$ for 16 hours. Total $\mathrm{C}$ and $\mathrm{N}$ content on milled samples was determined by mass-spectrometry gas chromatography (Europa Scientific, Model 20-20). Total P was determined by both X-ray fluorescence (XRF) spectrophotometry and on replicated samples by the ignition extraction procedure of Saunders and Williams as outlined by Olsen and Sommers (1982). Using this procedure total organic $\mathrm{P}$ content was determined by difference of ignited (total $\mathrm{P}$ ) and un-ignited (total inorganic $P$ ) samples extracted with $0.5 \mathrm{M} \mathrm{H}_{2} \mathrm{SO}_{4}$. Soils were also extracted with $0.5 \mathrm{M} \mathrm{NaHCO}_{3}$ for 30 mins as a measure of 'plant-available $\mathrm{P}$ ' (Olsen et al. 1954), whith both inorganic (as a measure of 'available' $\mathrm{P}$ ) and total $\mathrm{P}$ measured in the extracts. Total $\mathrm{P}$ was determined by acid-persulfate digestion following autoclaving $\left(120 \mathrm{kPa}, 121^{\circ} \mathrm{C}\right.$; $40 \mathrm{~min}$ ) of a $1 \mathrm{ml}$ subsample in the presence of $0.6 \mathrm{M} \mathrm{H}_{2} \mathrm{SO}_{4}$ and $3.3 \%$ ammonium persulphate (Schoenau and Huang 1991). In all cases molybdate reactive $P$ (MRP), as a measure of orthophosphate, was determined by direct assay of extracts with malachite green reagent using orthophosphate $P$ standards (Irving and McLaughlin 1990). Molybdate unreactive $P$ (MUP) was determined by difference of the direct extract MRP with the total $P$ as determined by acidpersulfate digestion. All samples were routinely measured using a 96 well microplate procedure with $80 \mu$ l of reagent and $200 \mu \mathrm{l}$ of sample at a wavelength of $620 \mathrm{~nm}$.

\section{Extraction of soils with organic anions.}

Soils were extracted with organic anions using a range of concentrations of citrate, oxalate and malate prior to analysis of MRP and MUP (by difference to the total P). Initially the Robertson and Grenfell soils (i.e., as representatives of high and low total soil P content; Table 1), were extracted with water (as control) and 0.4, 1.0, 4.0, 10.0 and $40.0 \mu \mathrm{mol}$ per gram of soil of each organic anion. In each case, seven grams of air-dried soil was equilibrated with a final volume of $28.0 \mathrm{ml}$ of organic anion solution that had been pre-adjusted with potassium hydroxide to the water-pH of the soil (i.e., pH 5.6 and pH 5.4 for the Robertson and Grenfell soils, respectively; Table 1). Organic anion solutions were prepared from stock solutions and added to soil $\left(\mu \mathrm{mol} \mathrm{g}^{-1}\right)$ by dilution to achieve final soil solution extraction concentrations of $0,0.1,0.25,1.0,2.5$ and $10.0 \mathrm{mM}$. All six soils were similarly extracted with water and 1.0 and $10 \mathrm{mM}$ of citrate, oxalate and malate, pre-adjusted in each case to the soil-water $\mathrm{pH}$ (Table 1). All extractions were performed in triplicate using 50 $\mathrm{ml}$ plastic screw-cap centrifuge tubes. Samples were extracted for $30 \mathrm{~min}$ at room temperature $\left(\sim 22^{\circ} \mathrm{C}\right)$ on an end-overend shaker at $\sim 30 \mathrm{rpm}$. The samples were subsequently centrifuged for $10 \mathrm{~min}(\sim 8000 \mathrm{~g} / 5,000 \mathrm{rpm})$ and the supernatant solutions recovered. Subsamples of the supernatant were withdrawn with a syringe and immediately passed through $0.22 \mu \mathrm{m}$ filters (MF-Millipore). Samples were then analyzed by the malachite green procedure for 
determination of MRP and MUP by difference with total P as previously outlined. Checks were conducted using orthophosphate standards to verify that the presence of the organic anions did not interfere with the colorimetric-based assay. Data was analyzed by one-way analysis of variance (ANOVA; Genstat, Release 20.1, VSN International, Hemel Hempstead, UK) with differences between means being determined by least significant difference (LSD) at $P=0.05$. Percentage data was also analyzed by arcsine transformation (\%/100) to confirm differences were consistent with untransformed data.

\section{Enzyme lability of extracted phosphorus}

The bioavailability of the MUP in the organic anion extracts for the six soils was evaluated by incubating the extracts with each of three preparations of phosphatases based on combinations of commercially available enzymes (Sigma Chemical Company).

1. Acid phosphomonoesterase (PME) from wheat germ; orthophosphoric-monoester phosphohydrolase Type 1, EC 3.2.3.2 (product P3627).

2. Phosphodiesterase (PDE) from Crotalus atrox (crude dried venom); phosphodiesterase I Type IV, EC 3.1.4.1 (product P4506).

3. Phytase (PHY) from Aspergillus ficuum (crude); myo-inositol-hexakisphosphate 3-phosphohydrolase (i.e, 3phytase), EC 3.1.3.8 (product P9792).

PME, PDE and PHY were specified by the supplier as $0.8,0.022$ and 3.5 Units of activity $\mathrm{mg}^{-1}$ solid, respectively. Each enzyme was dissolved in $50 \mathrm{mM}$ MES (2-N-morpholino ethanesulfonic acid) buffer adjusted to $\mathrm{pH} 5.5$ containing $5 \mathrm{mM}$ ethylenediaminetetraacetate (EDTA) and $2 \mathrm{mM} \mathrm{MgCl}$. The PHY solution was centrifuged at $1500 \mathrm{~g}$ for $10 \mathrm{~min}$ to remove particulate material and all preparations were then filter-sterilized by passage through a $0.22 \mu \mathrm{m}$ filter and stored at $4^{\circ} \mathrm{C}$ for prior to use. Previously we have shown that the PME preparation from Sigma had wide substrate specificity across a range of monoester (and diester) substrates including myo-inositol hexakisphosphate, glucose 1phosphate, ribonucleic acid, adenosine triphosphate, phosphoglyceric acid and the model subtracts $p$-nitrophenyl and bis $p$-nitrophenyl phosphate (Hayes et al. 2000). The Sigma PHY likewise was similarly active across these substrates, but importantly showed 47-times greater specific activity (per mg of protein) toward myo-inositol hexakisphosphate than PME, and also had greater specific activity toward diesters. As suggested by Hayes et al. (2000), the commercially available PHY preparation likely contained acid phosphatase activity as a contaminant. On this basis, the enzyme incubations in the present work were set up as PME alone, PME+PDE (to ensure that di-esterase activity was not limited) and PHY alone.

Enzyme assays were designed to run to completion with an excess of enzyme being added (Hayes et al. 2000). Each assay consisted of $4.5 \mathrm{ml}$ of water or organic anion extract (from above), $0.25 \mathrm{ml}$ of $0.1 \mathrm{M}$ sodium azide $\left(\mathrm{NaN}_{3}, 5 \mathrm{mM}\right.$ final concentration) to prevent microbial interference and $0.25 \mathrm{~mL}$ of $40 x$ MES-EDTA incubation buffer and enzyme mixture (PME, PME+PDE or PHY) that provided $0.1 \mathrm{U}$ of activity $\mathrm{ml}^{-1}$ of final assay (based on the enzyme activities specified by Sigma Chemical Company). This was equivalent to 1.67 nkat of total activity, or $1.5 \mathrm{nkat} \mathrm{g}^{-1}$ soil, where 1 nkat is defined by capacity to release 1 nmole of substrate $\sec ^{-1}$. Assays were conducted at a final buffer concentration of $50 \mathrm{mM}$ MES, $5 \mathrm{mM}$ EDTA, $2 \mathrm{mM} \mathrm{MgCl} 2$ and were incubated for $16 \mathrm{~h}$ at $37^{\circ} \mathrm{C}$ in $25 \mathrm{ml}$ plastic centrifuge tubes.

The concentrations of MRP following enzyme incubation were determined on completion of the reactions using the malachite green assay. The presence of enzymes at the concentrations used did not interfere with MRP detection as confirmed by running orthophosphate standards containing enzyme blanks, and there was no evidence of acid-induced hydrolysis during P detection by molybdate complexation. The amount of MUP hydrolyzed in each soil extract by PME, $\mathrm{PME}+\mathrm{PDE}$ or PHY was determined by subtracting initial MRP concentrations, with correction for enzyme-free blanks and 
any trace amounts of MRP present in the enzyme preparations. The amount of MRP released was also determined as a percentage of the total MUP prior to incubation. The data was analyzed by two-way ANOVA with differences between means being determined by LSD of the interaction (Extract x Enzyme) at $P=0.05$. Percentage data was also analyzed by arcsine transformation to confirm differences.

\section{Solution ${ }^{31} \mathrm{P}$ NMR spectroscopy}

Phosphorus was extracted from $10 \mathrm{~g}$ of the Robertson, Grenfell and Camden soils with $40 \mathrm{ml}$ of $10 \mathrm{mM}$ citrate, oxalate or malate (adjusted to pH 5.6 for the Robertson and Grenfell soils, and pH 5.5 for the Camden soil) in $50 \mathrm{ml}$ plastic tubes by end-over-end shaking for 1 hour at room temperature. The extractions were centrifuged for $30 \mathrm{~min}$ (8000 g) and supernatants filtered through $0.22 \mu \mathrm{m}$ membrane filters (MF-Millipore). A subsample was taken for determination of total $\mathrm{P}$ content following acid persulfate digestion. Extracts were then frozen $\left(-20^{\circ} \mathrm{C}\right)$ and freeze-dried (lyophilized) under vacuum at $-50^{\circ} \mathrm{C}$. Separate samples of the Robertson and Grenfell soils were also extracted for NMR analysis with 0.25 $\mathrm{M} \mathrm{NaOH}$ and $50 \mathrm{mM} \mathrm{Na}_{2}$ EDTA (sodium ethylenediaminetetraacetate) for $16 \mathrm{~h}$ at $22^{\circ} \mathrm{C}$ (Bowman and Moir 1993).

For NMR spectroscopy, lyophilized extracts $(\sim 100 \mathrm{mg})$ were-dissolved in $0.1 \mathrm{ml}$ of deuterium oxide and $0.9 \mathrm{ml}$ of a solution containing $1.0 \mathrm{M} \mathrm{NaOH}$ and $100 \mathrm{mM} \mathrm{Na}_{2}$ EDTA, and then transferred to a $5 \mathrm{~mm}$ NMR tube. The inclusion of EDTA was essential to yield acceptable spectral resolution. Solution ${ }^{31} \mathrm{P}$ NMR spectra were obtained using a Bruker Avance DRX $500 \mathrm{MHz}$ spectrometer (Bruker, Germany) operating at $202.456 \mathrm{MHz}$ for ${ }^{31} \mathrm{P}$. Samples were analyzed using a $6 \mu \mathrm{sec}$ pulse $\left(45^{\circ}\right)$, a delay time of $2.0 \mathrm{sec}$ and an acquisition time of $0.4 \mathrm{sec}$ with broadband proton decoupling. Approximately 30,000 scans were acquired for each sample. Spectra were plotted with a line broadening of $5 \mathrm{~Hz}$ and chemical shifts of signals were determined in parts per million (ppm) relative to an external standard of $85 \% \mathrm{H}_{3} \mathrm{PO}_{4}$. Signals were assigned to $\mathrm{P}$ compounds based on literature reports of model compounds spiked in $\mathrm{NaOH}-\mathrm{EDTA}$ soil extracts (Turner et al. 2003). Signal peaks were assigned following spectral deconvolution and integration of the peak areas was conducted to allow expression as a proportion (\%) of the total extracted P. Spectral processing was performed using NMR Utility Transform Software (NUTS) for Windows (Acorn NMR Inc., Livermore, CA).

\section{Results}

\section{Soil properties, $\mathrm{P}$ content and extractable $\mathrm{P}$}

The six soils used in the study were all moderately or strongly acidic (i.e., pH 6.3 to pH 5.4 in water) and showed contrasting properties in terms of soil organic matter content, $\mathrm{C}$ and $\mathrm{N}$ content and $\mathrm{P}$ characteristics with respect to total $\mathrm{P}$, percentage organic $\mathrm{P}$ and levels of extractable and available $\mathrm{P}$ (Table 1).

The pasture soil from Robertson had the largest $\mathrm{P}$ content with four to nine times more total P (by XRF) than the other soils and the cropping soil from Grenfell had the lowest P content (Table 1). This was consistent with the ranking of the soils for $\mathrm{P}$ content as determined by the ignition-extraction procedure (175.2 to $1540.6 \mathrm{mg} \mathrm{P} \mathrm{kg}^{-1}$ soil), where total $\mathrm{P}$ ranged from 57 to $87 \%$ of that measured by XRF. Across all six soils, organic $P$ accounted for $46-69 \%$ of the total $P$ content (110 to $1062 \mathrm{mg}$ organic $\mathrm{P} \mathrm{kg}^{-1}$ soil) as determined by extraction difference (ignited verses unignited) and was typically greatest as a percentage of total $\mathrm{P}(>65 \%)$ in the three pasture soils (Table 1$)$. The organic $\mathrm{P}$ concentration of the Robertson soil was 10 times greater than the Grenfell soil. Organic P content of the soils was also generally consistent with differences in organic matter content and soil C (Table 1). Whilst the C:N ratio of the soils was relatively consistent (11.1 to 12.5 across all soils), the $\mathrm{C}: \mathrm{P}$ and $\mathrm{C}$ :organic $\mathrm{P}$ ratios (based on extracted $\mathrm{P}$ ) were more variable ranging between 39 to 116 for $C: P$, and 56 to 184 for C:organic $P$, for the Robertson and Grenfell soils, respectively. These large differences in C:P ratios are likely related to soil type and management practices (including fertilizer history) that differentiate pasture from cropping soils. 
The 'availability of $\mathrm{P}$ ' as determined by bicarbonate extraction (Table 1) and water extraction (Table 2) similarly differed across the six soils. Between $2.4-17.9 \%$ of the total P (for Robertson and Grenfell, respectively) was extracted with bicarbonate (ranging from 27.1 to $36.8 \mathrm{mg} \mathrm{P} \mathrm{kg}^{-1}$ soil). Importantly, and despite the similarity in concentration of the extractable P across the soil, the proportion of the total P that was 'available' as inorganic P (identified as MRP) was highly variable, ranging from $15 \%$ for the Wallaroo pasture soil, to $57 \%$ for the Greenthorpe and Berthong cropping soils. By contrast, the level of 'unavailable' $P$ in the bicarbonate extracts across the soils (identified as MUP) was large and greater than $43 \%$ of the total (Table 1 ). Water similarly extracted a small amount of the total soil $\mathrm{P}(<1 \%$ across all soils, concentration ranging from 1.03 to $5.23 \mathrm{mg} \mathrm{P} \mathrm{g}^{-1}$ soil) with between $40 \%$ (Greenthorpe) and 97\% (Robertson) of the $\mathrm{P}$ present in the water extracts being molybdate unreactive (MUP; Table 2) 
Table 2

Organic anion extraction of phosphorus $(P)$ from six Australian soils. Shown are the concentrations (mg P kg soil-1) of molybdate-reactive P (MRP) and molybdate-unreactive P (MUP), and the proportion (\%) of the total extracted P measured as MUP. Soils were extracted by water and by citrate, oxalate, and malate each at two concentrations ( 1 and $10 \mathrm{mM})$.

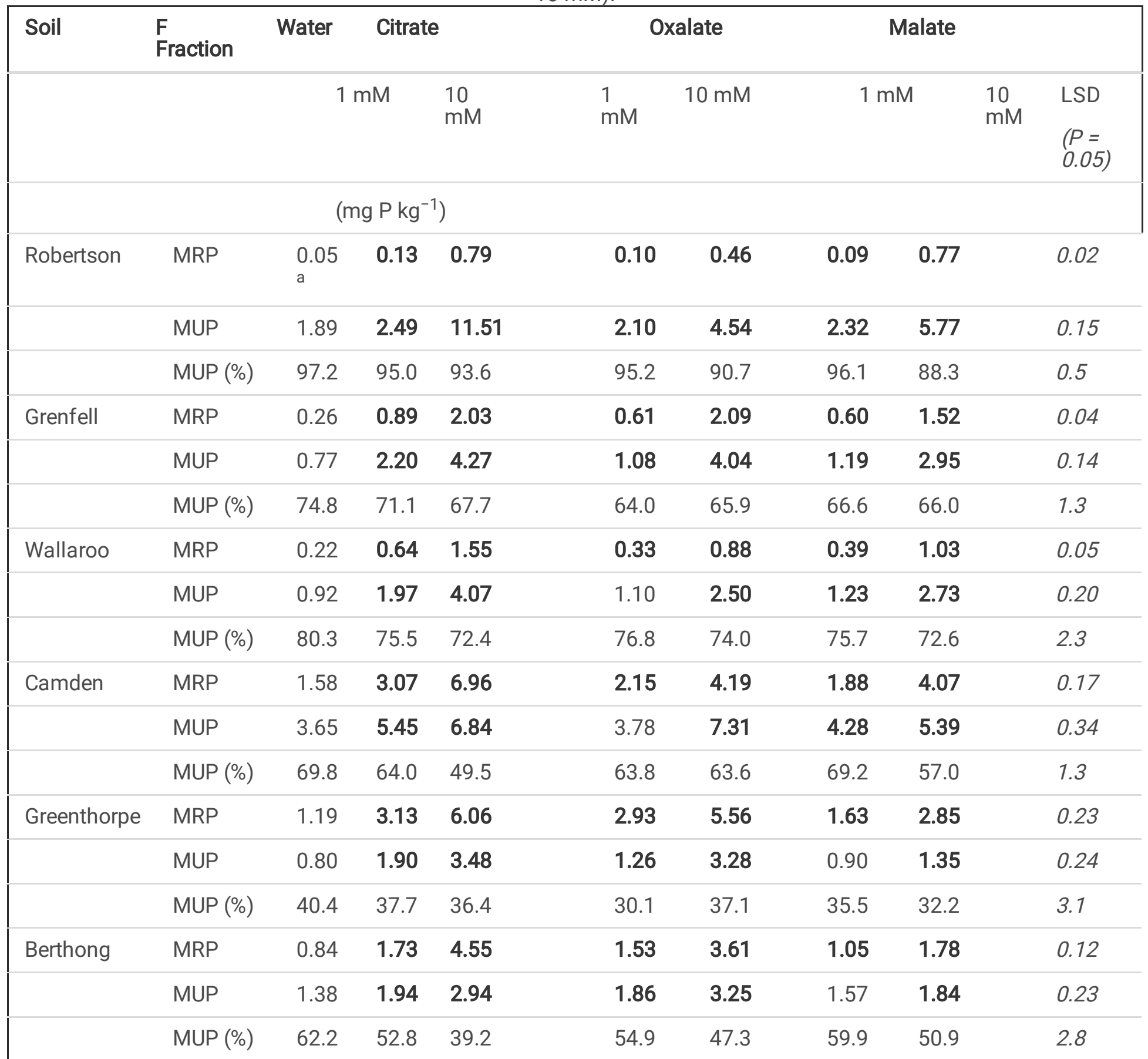

a Values are the mean of 3 replicates $(n=3)$ and for each row the least significant difference (LSD) across the extraction treatments is shown. MRP and MUP extraction values shown in bold are significantly different $(P=0.05)$ to the water control.

\section{Extraction of soil P by organic anions.}


The capacity of organic anions to extract MRP and MUP from soil was assessed by first extracting the Robertson and Grenfell soils with increasing concentrations of citrate, malate and oxalate up to $40.0 \mu \mathrm{mol} \mathrm{g}^{-1}$ soil (equivalent to 10 $\mathrm{mM}$ solution concentration, Figure 1). Then all six soils with the organic anions at $1 \mathrm{mM}$ and $10 \mathrm{mM}$ (Table 2), concentrations that were expected to relevant to that found for cluster roots of white lupin.

The three organic anions showed a concentration dependency for extraction of both MRP and MUP as compared to water as control (Figure 1). All three organic anions extracted less MRP from the Robertson soil than from the Grenfell soil in terms of both absolute concentrations ( $<0.75 \mathrm{mg} \mathrm{P} \mathrm{g}^{-1}$ soil in all cases) and as a percentage of the total $\mathrm{P}$ extracted (average of 2.7\%). The MUP extracted from the Robertson soil by citrate, oxalate and malate was considerably greater than the MRP and accounted for 93 to $97 \%, 91$ to $97 \%$ and 88 to $98 \%$ of the total P extracted, respectively. There was strong linear correlation $\left(R^{2}>0.996\right)$ between organic anion concentration and the MRP and MUP extracted in the Robertson soil with citrate being most effective at mobilizing MUP (Figure 1). By contrast, the extraction of MRP and MUP in the Grenfell soil showed more of a saturating relationship and the amounts of $\mathrm{P}$ extracted were comparable at the highest concentration of each organic anion. The proportion of the total P extracted as MUP in the Grenfell soil was less than the Robertson and ranged from 64 to $76 \%$ across the three organic anions.

The relative effectiveness of organic anions in mobilizing MRP and MUP was also assessed at two concentrations (1 $\mathrm{mM}$ and $10 \mathrm{mM}$ ) for each organic anion across the six soils. The concentration of MRP in extracts was increased significantly $(P<0.05)$ by all three organic anions (Table 2$)$. Across the soils, the average increase in MRP extracted at $10 \mathrm{mM}$ (relative to water extract) was 7.3-fold for citrate and 5.3-fold for both oxalate and malate. At $1 \mathrm{mM}$, the comparable increase in MRP across the three organic anions was 1.6, 1.9 and 2.6-fold for oxalate, malate and citrate respectively. For all soils, a large proportion of the extracted P occurred as MUP and accounted for 62 to $94 \%$ of the total $P$ for the three pasture soils and 36 to $68 \%$ for the three cropping soils (Table 2 ). In most cases, the MUP extracted by organic anions was significantly greater (1.3 to 4.1-fold) than the MUP extracted by water. The exceptions were $1 \mathrm{mM}$ oxalate in the Wallaroo and Camden pasture soils and $1 \mathrm{mM}$ malate in the Berthong cropping soil.

\section{Phosphatase enzyme lability of extracted phosphorus}

Incubation of the organic anion extracts with different combinations of phosphatase enzymes resulted in increased levels of MRP through the hydrolysis of MUP. In most cases, the release of MRP was significantly greater than the water control (Table 3). In the water extracts, addition of the PME, PME+PDE and PHY phosphatase preparations liberated 10 to $31 \%, 8$ to $27 \%$ and 19 to $38 \%$, respectively, of the MUP across the six soils (Figure 2). In the organic anion extracts, both the MRP concentration (Table 2) and the percentage of the MUP released (Figure 2) was increased, with strong interactions occurring between the enzyme preparation and the type and concentration of organic anion. 
Table 3

Concentrations of enzyme-labile phosphorus $(P)$ following extraction of soil with organic anions and incubation with phosphatase enzymes. Shown is the concentration of molybdate-reactive P (MRP) following incubation of soil extracts with phosphomonoesterase (PME), PME in combination with phosphodiesterase (PME + PDE), or with phytase (PHY). The values represent the increase in MRP from levels prior to incubation. Soils were extracted by water and by citrate, oxalate, and malate each at two concentrations (1 and $10 \mathrm{mM})$.

\begin{tabular}{|c|c|c|c|c|c|c|c|c|c|c|c|}
\hline Soil & Enzyme & Water & Citrat & & & ralate & & & alate & & \\
\hline & & & $\begin{array}{l}1 \\
\mathrm{mM}\end{array}$ & $\begin{array}{l}10 \\
\mathrm{mM}\end{array}$ & & $\begin{array}{l}1 \\
\mathrm{mM}\end{array}$ & $\begin{array}{l}10 \\
\mathrm{mM}\end{array}$ & & $\begin{array}{l}1 \\
\mathrm{mM}\end{array}$ & $\begin{array}{l}10 \\
\mathrm{mM}\end{array}$ & $\begin{array}{l}\text { LSD } \\
(P= \\
0.05)\end{array}$ \\
\hline & & & $\mathrm{P} \mathrm{kg}^{-}$ & & & & & & & & \\
\hline Robertson & PME & $0.19^{a}$ & 0.44 & 3.46 & 0.24 & 0.89 & & 0.34 & 1.74 & & \\
\hline & PME+PDE & 0.15 & 0.49 & 4.20 & 0.16 & 0.73 & & 0.34 & 1.95 & & 0.14 \\
\hline & $\mathrm{PHY}$ & 0.38 & 0.53 & 6.75 & 0.61 & 1.65 & & 0.55 & 2.59 & & \\
\hline Grenfell & PME & 0.13 & 0.49 & 0.49 & 0.21 & 0.47 & & 0.37 & 0.68 & & \\
\hline & PME+PDE & 0.13 & 0.67 & 0.80 & 0.22 & 0.52 & & 0.40 & 0.97 & & 0.05 \\
\hline & PHY & 0.18 & 1.40 & 2.24 & 0.32 & 1.57 & & 0.44 & 1.67 & & \\
\hline Wallaroo & PME & 0.28 & 0.77 & 1.10 & 0.43 & 0.66 & & 0.55 & 0.96 & & \\
\hline & $\mathrm{PME}+\mathrm{PDE}$ & 0.25 & 0.84 & 1.60 & 0.36 & 0.70 & & 0.58 & 1.42 & & 0.09 \\
\hline & $\mathrm{PHY}$ & 0.35 & 1.22 & 2.52 & 0.59 & 1.40 & & 0.60 & 1.71 & & \\
\hline Camden & PME & 0.53 & 1.86 & 2.18 & 0.58 & 1.09 & & 0.97 & 1.74 & & \\
\hline & $\mathrm{PME}+\mathrm{PDE}$ & 0.62 & 2.01 & 2.41 & 0.63 & 1.35 & & 1.43 & 2.22 & & 0.19 \\
\hline & $\mathrm{PHY}$ & 0.81 & 2.60 & 3.45 & 0.91 & 2.25 & & 1.42 & 2.45 & & \\
\hline Greenthorpe & PME & 0.21 & 0.48 & 0.88 & 0.25 & 0.43 & & 0.44 & 0.79 & & \\
\hline & PME+PDE & 0.18 & 0.55 & 1.05 & 0.31 & 0.80 & & 0.32 & 0.71 & & 0.10 \\
\hline & $\mathrm{PHY}$ & 0.18 & 0.49 & 1.06 & 0.27 & 0.97 & & 0.23 & 0.55 & & \\
\hline Berthong & PME & 0.26 & 0.44 & 0.63 & 0.21 & 0.45 & & 0.43 & 0.50 & & \\
\hline & $\mathrm{PME}+\mathrm{PDE}$ & 0.23 & 0.51 & 0.84 & 0.32 & 0.68 & & 0.32 & 0.47 & & 0.13 \\
\hline & PHY & 0.27 & 0.48 & 0.74 & 0.35 & 0.95 & & 0.27 & 0.47 & & \\
\hline
\end{tabular}

a Values are the mean of 3 replicates $(n=3)$ and for each soil the least significant difference (LSD) for the Enzyme $x$ Extract interaction $(P=0.05)$ is shown, with values shown in bold for each of the enzymes being significantly different when compared to the water control for that enzyme. The main effect of Extract was significant $(P<0.001)$ for all soils, and for Enzyme; PME < PME+PDE < PHY $(P<0.001)$ for Robertson, Grenfell, Wallaroo and Camden soils; $\mathrm{PME}<\mathrm{PHY}$, and PME+PDE = both PME and PHY $(P=0.01)$ for Greenthorpe soil and PME = PME+PDE = PHY for Berthong soil.

In terms of the observed increases in MRP concentrations presented in Table 3, all extractants (water and the three organic anions) and enzyme preparations (PME, PME+PDE and PHY) had significant effects. The $10 \mathrm{mM}$ organic anion 
treatments in combination with all enzyme preparations increased the MRP concentration, with citrate being the most effective across all soils. The next most effective on the three pasture soils and Grenfell soil was malate followed by oxalate, whereas on the Greenthorpe and Berthong cropping soils, with their lower total organic P contents (Table 1) and smaller proportions of organic $\mathrm{P}$ (with all organic anion extracts, Table 2), oxalate was more effective than malate. The $10 \mathrm{mM}$ citrate extraction increased MRP release by 7.8-fold (on average compared with the water controls) across all soils with a range from 2.9-fold, in the Berthong soil, to 20.1-fold in the Robertson soil. By comparison, the average MRP released with $10 \mathrm{mM}$ oxalate across all soils was 3.8-fold and 5.0-fold for $10 \mathrm{mM}$ malate. At the lower $1 \mathrm{mM}$ organic anion treatments, the average MRP released was 3.2,1.4 and 1.9-fold for citrate, oxalate and malate respectively. Interestingly, $1 \mathrm{mM}$ oxalate was generally ineffective on all soils except for Grenfell and Wallaroo, and $1 \mathrm{mM}$ malate treatment showed strong interactions with the enzyme preparations on the Greenthrope and Berthong soils. By contrast, $1 \mathrm{mM}$ citrate increased MRP on all soils compared with water controls and with each of the enzyme preparations (Table 3).

The relative effectiveness of the different phosphatases in releasing MRP varied with soil type and showed interactions with the extractants. Across the three enzymes, the PHY preparation resulted in significantly greater increase in MRP than PME in all soils except for Berthong. Incubation of extracts with PHY enzyme was also more effective than $\mathrm{PME}+\mathrm{PDE}$ in all soils except for the Greenthorpe and Berthong soils. Across the enzyme preparations the PME, PME+PDE and PHY increased the concentrations of MRP by an average of 3.2-fold (range 1.7 to 6.3), 4.3-fold (range 2.3 to 8.8 ) and 4.1-fold (2.0 to 7.2), respectively, relative to that observed for the water controls (Table 3).

In addition to the increases in MRP concentration mediated by the phosphatases in the organic anion extracts, the proportion of the MUP hydrolyzed by the phosphatases (i.e., enzyme-lability) was also significantly increased (Figure 2). When averaged across all the organic anion extracts, the lability of the MUP was increased by $1.4,1.7$ and 1.6-fold for the PME, PME+PDE and PHY preparations, respectively (relative to the combined average in water). Once again, clear interactions were evident between the different enzyme preparations and soil types (Figure 2). The PHY preparation was significantly more effective than the PME in the Robertson, Grenfell, Wallaroo and Camden soils, but was less effective than PME in the Greenthorpe soil. The PME+PDE preparation was more effective than PME only in the Grenfell, Wallaroo and Camden soils but equivalent to PME in the Robertson and Greenthorpe soils. There was no difference between the three phosphatase enzymes in the Berthong soil, where MUP lability increased by an average of 1.3-fold across the enzyme and extractant combinations. In all cases, however, the effect of the organic anion extractant was significant $(P$ $<0.001$ ) with citrate generally being most effective (1.6 and 1.8-fold at 1 and $10 \mathrm{mM}$ across all soils). Citrate was effective in most soils (especially in combination with PHY), with the excepts being the two cropping soils (Greenthorpe and Berthong) with their lower organic P contents. Enzyme-lability in the malate and oxalate extracts showed strong interactions with soil type, extractant concentration and phosphatase preparation. Interestingly, malate was more effective than citrate or oxalate in the Greenthorpe soil (especially for PME and PME+PDE), and relatively more effective than oxalate for all three enzymes across the other five soils (Figure 2).

\section{Solution ${ }^{31} \mathrm{P}$ NMR spectroscopy of organic anion extracts}

Solution ${ }^{31}$ P NMR spectroscopy was used to identify the P compounds extracted from the Robertson, Grenfell and Camden soils with $10 \mathrm{mM}$ citrate, oxalate and malate. Whilst the quality of the spectra (as compared to NaOH-EDTA) varied markedly across extractants and soils (Figure 3), orthophosphate and phosphomonesters were clearly identified as the major forms of extracted $\mathrm{P}$ (Table 4). 
Table 4

Phosphorus $(P)$ composition of soil extracts determined by solution ${ }^{31} \mathrm{P}$ NMR spectroscopy. Soils were extracted with 10 $\mathrm{mM}$ organic anions (citrate, oxalate or malate) or $\mathrm{NaOH}$-EDTA (not determined for Camden) and the proportion of $\mathrm{P}$ within recognizable classes of $\mathrm{P}$ compounds expressed as a percentage of the total $\mathrm{P}$ extracted.

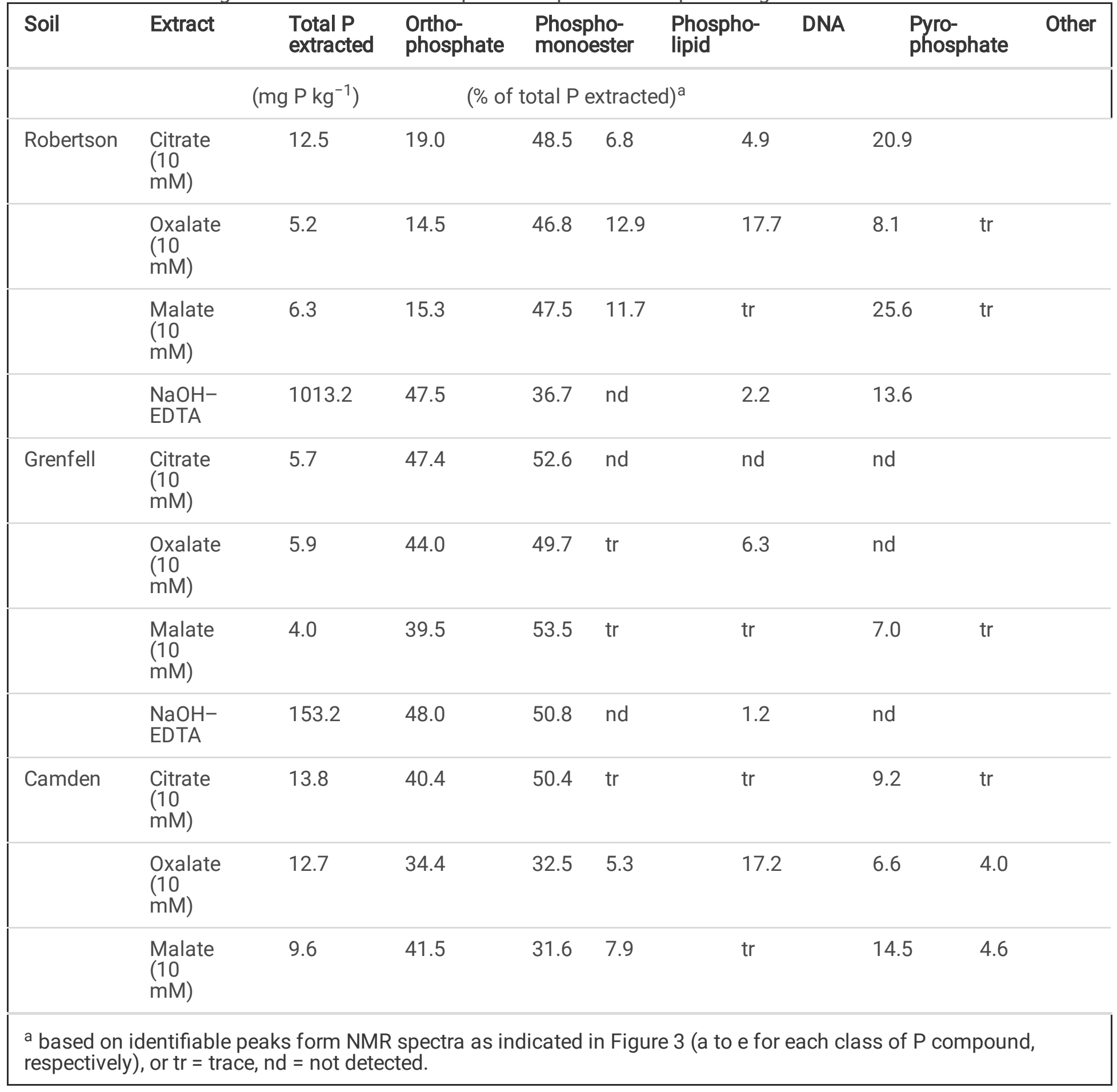

Across the three organic anion extracts, phosphomonesters constituted 46.8 to $48.5 \%$ of the P in the Robertson soil, 49.7 to $53.5 \%$ in the Grenfell soil and 31.6 to $50.4 \%$ in the Camden soil. Within the monoester region, spectral peaks characteristic of myo-inositol hexakisphosphate were present in the malate extractions across all three soils (Figure 3; Turner et al. 2003). A signal close to $\delta=4.2 \mathrm{ppm}$ in several soils (e.g., Grenfell soil and to a lesser extent the Camden soil) could similarly be assigned potentially to scyllo-inositol hexakisphosphate (Turner and Richardson 2004). Of the 
phosphodiesters, phospholipids constituted a considerable fraction of the extracted P (up to 12.9\%) in the Robertson and Camden soils especially with malate and oxalate extracts. By contrast only trace amounts of phospholipids were evident in extracts from the Grenfell soil. Nucleic acids (potentially as DNA) accounted for a considerable proportion of the extracted $P$ in the oxalate extracts from all three soils (6.3 to 17.7\%). An additional unidentified phosphodiester was detected near $\delta=-2.1 \mathrm{ppm}$ which accounted for 4.0 to $4.6 \%$ of the extracted $P$ in malate and oxalate extracts of the Camden soil, and trace amounts in the malate extracts of the other two soils. Pyrophosphate was detected in all extracts (6.6 to $25.6 \%$ ) of the Robertson and Camden soils, particularly in the citrate and malate extracts, but only in the malate extract of Grenfell soil (Table 4).

The P speciation in the extraction spectra were supported by NMR analysis of total P extracted in $\mathrm{NaOH}-\mathrm{EDTA}$ for the Robertson (1013 $\mathrm{mg} \mathrm{P} \mathrm{kg}^{-1}$ ) and Grenfell (153 $\mathrm{mg} \mathrm{P} \mathrm{kg}^{-1}$ ) soils (Figure 3; the Camden soil was not analyzed by $\mathrm{NaOH}-$ EDTA extraction). These concentrations of the $\mathrm{NaOH}$-extracted $\mathrm{P}$ represented $66 \%$ and $87 \%$ of that extracted by $\mathrm{H}_{2} \mathrm{SO}_{4}$ for the Robertson and Grenfell soils, respectively (Table 1), and were considerably greater (by 30 to 126-fold) than the amount of $\mathrm{P}$ extracted by the organic anions (Table 4). For both soils, $\mathrm{NaOH-EDTA} \mathrm{extracts} \mathrm{were} \mathrm{similarly} \mathrm{dominated} \mathrm{by}$ orthophosphate ( 48\% of extracted P) and phosphomonoesters (36.7 to 50.8\% for Robertson and Grenfell, respectively). Nucleic acids (as DNA) were present at smaller proportions in both soils (1.2 to 2.2\%), while the Robertson soil contained a larger proportion of pyrophosphate (13.6\%). Phospholipids were not detected in $\mathrm{NaOH}-\mathrm{EDTA}$ extracts of either soil, presumably due to their degradation during $\mathrm{Na}-\mathrm{OH}$ extraction (Turner et al. 2003), which is in direct contrast to their predicted presence (up to 13\%) in the organic anions extracts in the Robertson and Grenfell soils (Table 4).

\section{Discussion}

Across six contrasting soils we showed that citrate, oxalate and malate were effective in extracting P and that this reaction was dependent on both soil type and extractant concentration. Extracted $P$ was evident as both MRP (presumably mostly as orthophosphate) and MUP, which would be expected to include a range of organic and condensed forms of P. These extractions were analyzed with NMR and the presence of orthophosphate, pyrophosphate and various monoester and diester forms of $\mathrm{P}$ was confirmed. Importantly, we also showed that the addition of the PHY, PME and PDE phosphatases, either separately or in combination, significantly increased the MRP content of most extracts, with up to $\sim 60 \%$ of the MUP being enzyme labile (depending on the treatment). This provides strong evidence for the biological potential of a combination of organic anions and phosphatases to mobilize soil P from both inorganic and organic pools.

\section{Effectiveness of organic anions for extraction of soil P}

Both the total amount of P extracted by organic anions and relative contribution of MUP as a proportion of the total $\mathrm{P}$ extracted, varied considerably across the soils. The total amount extracted was related to total soil P content, and the proportion within the MUP fraction was generally less in the cropping soils which had lower total organic $P$ contents (e.g., Greenthorpe and Berthong). The effectiveness of each organic anion to extract $P$ thus varied with soil type. For example, $10 \mathrm{mM}$ citrate was more effective than similar concentrations of malate or oxalate at mobilizing $\mathrm{P}$ in the Robertson and Wallaroo soils, whereas oxalate and citrate were equally effective in several soils, particularly the cropping soils (i.e., Grenfell, Greenthrope and Berthong). Malate was generally less effective than oxalate, except on the Robertson and Wallaroo soils which are the most acidic. The Robertson soil (Ferrosol) also has high Fe and Al contents. The finding that the organic anions differ in their capacity to mobilize $\mathrm{P}$ was not unexpected since many reports have shown that tricarboxylic acids like citrate are generally more effective than dicarboxylates like oxalate and malate. Furthermore, the $\mathrm{pH}$ of the organic anion solutions were adjusted to match the water-based pH of each soil (Table 1).

Page $15 / 25$ 
This means that the $\mathrm{pH}$ of the extraction solutions were different and, therefore, the degree of dissociation (or protonation) of the carboxyl groups of the extractants would also vary according the pKa profile of each organic acid. This would be particularly important for citrate with three $\mathrm{pKa}$ at $\mathrm{pH} \sim 3.1,4.8$ and 6.4. Nonetheless, the interaction between soil type and the capacity of different organic anions to release $P$ suggest that mobilization of $P$ occurred from different soil pools of the inorganic and/or organic $P$ fractions.

Whilst our study investigated each organic anion in isolation, it would be interesting to investigate the effectiveness of combining the organic anions since this would better mimic the conditions in the rhizosphere (Nuruzzaman et al. 2006; Pearse et al. 2006; Wang et al. 2013; Wouterlood et al. 2004). Whether or not specific organic anions, or different compositions of organic anions, provide a 'niche' advantage for different crops (or genotypes) to mobilize different pools of sparingly available $P$ in different soils has been subject of much speculation and remains unclear (Lambers et al. 2002; Pearse et al 2007; Veneklaas et al. 2003). Niche differentiation, with regard to P acquisition, may have significance for ecological function and the evolutionary adaption of plants to different soils and environments (Turner 2008).

\section{Positive interaction of phosphatases and organic anions}

This study clearly demonstrated that the effectiveness of phosphatases to increase P availability from organic pools was enhanced after the soil was first extracted with organic anions. This was evident from the 'phosphatase-mediated' increase in MRP content in most organic anion extracts and by the 'increase in the lability' of the organic P mobilized, as indicated by a greater proportion of the MUP that was amenable to hydrolysis by enzymes (Figure 2). There were, however, strong interactions between the enzyme preparations, soil types and extractants. For example, while phytase (PHY) was generally the most effective phosphatase across all soils and extractants, it was most effective when used in combination with citrate except for the Greenthorpe and Berthong cropping soils. With few exceptions, the effectiveness of the monoesterase (PME) was no different to the combination of PME with the diesterase (PDE). In this regard some 'endogenous' phosphatase activity in the soil extracts cannot be excluded and this was supported by the low levels of activity detected in the water controls. Nonetheless, direct addition of the phosphatase enzymes (either PME, PDE or $\mathrm{PHY}$ ) increased the concentrations of MRP above the water controls indicating additional P mobilization occurred. Such observations provide further insights into the forms of $\mathrm{P}$ mobilized in the soils by the organic anions.

The observation that the PHY preparation was the most effective phosphatase suggests that the organic anions were particularly effective in mobilizing inositol phosphates that were either adsorbed in the soil or possibly associated with high molecular weight organic matter and/or sparingly-soluble precipitates. Indeed, Celi and Barberis (2005) have shown that, similar to orthophosphate, inositol hexkisphosphates are readily adsorbed in soils through interactions with four of the six negatively charged monoester-phosphate moieties. Importantly, Giaveno et al. (2010) demonstrated that inositol hexakisphosphates were not amendable to dephosphorylation by phytases when adsorbed to the solid phase (soil clays and iron-oxide minerals) presumably due to steric hinderance between substrate and enzyme. Precipitated forms of inositol phosphates (e.g., Al- and Fe-phytates) have similarly been shown to be less susceptible to dephosphorylation by a range of phytases (Tang et al. 2006). Tang et al. (2006) also showed that the addition of citrate, and to a lesser extent malate and oxalate, improved the lability of substrates to phytase activity. Interestingly, in these experiments the presence of $\mathrm{Al}^{3+}$ and $\mathrm{Fe}^{2+/ 3+}$ also inhibited the hydrolysis of Ca-phytate but this inhibition could be reduced when citrate was added. Citrate may influence the desorption kinetics of inositol hexakisphosphates from soil minerals just as it does for orthophosphate (Martin et al. 2004). These studies, in combination with our findings here, suggest that the amenability of inositol hexakisphosphates and other forms of organic $P$ to hydrolysis is enhanced by the presence of organic anions. 
The complementary activity of organic anions and phosphatase enzymes for mobilizing $\mathrm{P}$ has important implications for the bioavailability of $\mathrm{P}$ in soil for plant nutrition and microbial processes. For example, it has been widely suggested that the effectiveness by which white lupins are able to mobilize and acquire $P$ is a combination of root structural and functional traits (Lambers et al. 2013). Indeed 'the success' of white lupin to acquire P appears to rely on both the formation of cluster roots and 'their cocktail' of exudates, comprised of organic anions, protons, phosphatases and secondary metabolites to inhibit microbial activity (Neumann et al. 1999; Weisskopf et al. 2006). The phosphatases released by white lupin include isoforms with a broad specificity including those with phytase activity (Tadano et al. 1993; Maruyama et al. 2012). Moreover, when tobacco plants were genetically modified to enhance citrate and phytase exudation together, they showed a greater ability to utilize organic $P$ from soils than lines modified to release citrate or phytase alone (Giles et al. 2017). The evolution of combinatory approaches such as these by plants to mobilize and acquire soil $\mathrm{P}$ is therefore expected to improve their resilience to $\mathrm{P}$ stress and, potentially, to provide a competitive advantage through resource partitioning as proposed by Turner (2008).

\section{Direct evidence for extraction of organic phosphate compounds by organic anions}

This study used ${ }^{31} \mathrm{P}$ NMR to confirm and identify the forms of $\mathrm{P}$ extracted from soil by organic anions. The compounds released depended on soil type and the organic anion used but included a range of monoesters (including inositol hexakisphosphates), diesters (including phospholipids, DNA and unidentified compounds that are likely diesters) and pyrophosphate. Even though the release of these compounds with organic anions was small compared with a $\mathrm{NaOH}$ EDTA-extraction, it is the first example, to our knowledge, of NMR analysis being applied to demonstrate directly the mobilization of soil organic P by organic anions. The 'quality' of the NMR spectra was considered to be high for the Grenfell and Camden soils (Figure 3) but more variable for the Robertson soil. Nevertheless, compounds across all soils could be assigned to the peaks according to chemical shifts obtained from the NaOH-EDTA extractions (Turner et al. 2003). These peaks should be verified in future experiments with 'spiked' controls. Furthermore, EDTA had to be included in the extraction samples to obtain reliable NMR spectra (data not shown), which was particularly important for the Robertson (Ferrosol) soil where high $\mathrm{Fe}^{2+/ 3+}$ and $\mathrm{Al}^{3+}$ content may have contributed to the poorer spectral quality.

The effectiveness of the organic anions in mobilizing different $\mathrm{P}$ compounds varied both within and across the soils and often contrasted with the $\mathrm{NaOH}$-EDTA extractions. For example, phospholipids were present in all the organic anion extracts of the Robertson soil, but they were not evident in the $\mathrm{NaOH}$-EDTA extractions. Moreover, phospholipids were absent in extracts of Grenfell soil but were more variable in the Camden soil. Nucleic acids as DNA was most efficiently extracted by oxalate across all three soils while pyrophosphate was most prevalent in the citrate and malate extracts. Whether these differences are a direct effect of an extraction efficiency from different soil pools or are a consequence of varying degrees of degradation during and post-extraction across the different soils remains to be determined. Indeed it is feasible that the organic anions were effective in extracting a large component of microbial P as indicted by generally high content of DNA and phospholipids across the various extracts. Moreover, monoester forms of organic $\mathrm{P}$ were consistently identified (32-53\% of total extracted $\mathrm{P}$ ) from the three soils extracted with the three organic anions. Spectral signals that were indicative of both myo- and scyllo-inositol hexakisphosphate were particularly evident in the majority of organic anion extracts, especially in the Robertson and Grenfell soils extracted with malate (Figure 3).

Importantly, the variable detection of monoester and diester $\mathrm{P}$ substrates, including inositol phosphates, in the organic anion extracts is consistent with the observed increases in MRP and the lability of MUP to dephosphorylation by combinations of PHY, PME and PDE. Further work is needed to better link activity of the different phosphatases with the dephosphorylation of specific organic $\mathrm{P}$ compounds. Ideally this would require the use of highly purified enzymes with more defined substrate specificities, as compared to the commercial enzyme preparations that were used in the present study. Assessment of different organic anions extracts both before and after phosphatase treatment would also be

Page $17 / 25$ 
informative for identifying specific substrates that were enzyme-labile. Whilst this could initially be achieved using laboratory incubations, as conducted here, in the longer term these experiments should be directed at rhizosphere samples from plants that show different exudation profiles for organic anions and phosphatases. Based on a range of

observations from different experimental systems, we further propose that increasing the release of both organic anion exudation and phosphatases (particularly phytase) from roots may be a viable strategy for increasing the P-use efficiency of plants through greater mobilization of soil P (e.g., Giles, et. 2018; Giles et al. 2016, Ryan et al. 2004, Richardson et al. 2011, George et al. 2005).

Collectively, our findings demonstrate the potential importance of combining organic anion and phosphatase exudation from roots for manipulating $P$ dynamics in the soil and for enhancing plant nutrition. This study provides insights into the soil chemistry of natural and agroecosystems and contributes to ongoing efforts to improve the P-use efficiency of crop plants.

\section{Declarations}

This work was initiated through a Grains Research and Development (GRDC) supported research project awarded to PJH (CSP318). The authors declare that no other direct funds or grants were received during the preparation of this manuscript and that the authors were otherwise supported by their indicated host institutions. The authors have no relevant financial or non-financial interests to disclose. All authors contributed to the study conception and design. Data collection and analysis was initially conducted by M. Hens and completed by A. Richardson The first draft of the manuscript was written by A. Richardson and all authors (with exception of PJH) have provided comment to the paper and approved the final manuscript. The datasets generated and analyzed in the study are available from the corresponding author on reasonable request.

\section{Acknowledgements}

This paper was prepared in specific tribute to Professor Hans Lambers as Chief Editor for Plant and Soil. The data was compiled from historic data sets that were generated through a Grains Research and Development (GRDC) supported industry-based project awarded to CSIRO (CSP318) that was conducted 2001 to 2003 . The experimental work was undertaken by $\operatorname{Dr}$ M. Hens as a post-doctoral scientist under the supervision and in the laboratory of the late $\mathrm{Dr} P$. Hocking. We thank Dr Ben Turner for coordinating the NMR analysis and providing interpretation of the spectral data. The experimental work was conducted as part of the core effort of the CSIRO Plant Nutrition Group, who are represented as authors of the paper. The long-standing interaction of the Plant Nutrition Group with Professor Lambers and his laboratory at University of WA is greatly appreciated. In particular, the shared interests in the role of organic anions in mobilization of soil P, especially through the uniqueness of Australian native plants and in response to P deficiency that is very common across most Australian soils is acknowledged. In support of Prof Lambers, R. Simpson, P. Ryan, T. George and E. Delhaize have contributed to Plant and Soil as Section or Consulting Editors. In collaborative work with the Lambers Group, A. Richardson and R. Simpson have been adjunct Professors at UWA. Contribution of T George to this work was also supported by the Scottish Government. We thank Alex Blumenfeld (University of Idaho) for NMR technical support and also the many technicians at CSIRO that have supported the plant nutrition work conducted by the Group over many years.

\section{References}

1. Barrow NJ (2017) The effects of pH on phosphate uptake from the soil. Plant Soil 410:401-410 
2. Bowman RA, Moir JO (1993) Basic EDTA as an extractant for soil organic phosphorus. Soil Sci Soc Amer J. 57:1516-1518

3. Bünemann EK (2008) Enzyme additions as a tool to assess the potential bioavailability of organically bound nutrients. Soil Biol Biochgem 40:2116-2129

4. Celi L, Barberis E (2005) Abiotic stabilization of organic phosphorus in the environment. In: Turner BL, Frossard E, Baldwin D (eds) Organic phosphorus in the environment. CABI Publishing, Wallingford, pp 113-132

5. Darch T, Blackwell MSA, Chadwick D, Haygarth PM, Hawkins JMB, Turner BL (2016) Assessment of bioavailable organic phosphorus in tropical forest soils by organic acid extraction and phosphatase hydrolysis. Geoderma 284:93-102

6. Dinkelaker B, Romheld V, Marschner H (1989) Citric acid excretion and precipitation of calcium citrate in the rhizosphere of white lupin (Lupinus albus L). Plant Cell Environ 12:285-292

7. George TS, Richardson AE, Smith JB, Hadobas PA, Simpson RJ (2005) Limitations to the potential of transgenic Trifolium subterraneum L. plants that exude phytase, when grown in soils with a range of organic $\mathrm{P}$ content Plant and Soil 258:263-274

8. George TS, Giles CD, Menezes-Blackburn D, Condron LM, Gama-Rodrigues AC, Jaisi D, Lang F, Neal AL, Stutter MI, Almeida DS, Bol R, Cabugao KG, Celi L, Cotner JB, Feng G, Goll DS, Hallama M, Krueger J, Plassard C, Rosling A, Darch T, Fraser T, Giesler R, Richardson AE, Tamburini F, Shand CA, Lumsdon DG, Zhang H, Blackwell MSA, Wearing C, Mezeli MM, Almas AR, Audette Y, Bertrand I, Beyhaut E, Boitt G, Bradshaw N, Brearley CA, Bruulsema TW, Ciais P, Cozzolino V, Duran, PC, Mora ML, de Menezes AB, Dodd RJ, Dunfield K, Engl C, Frazao JJ, Garland G, Jimenez J LG, Graca J, Granger SJ, Harrison AF, Heuck C, Hou EQ, Johnes PJ, Kaiser K, Kjaer HA, Klumpp E, Lamb AL, Macintosh K A, Mackay EB., McGrath, J, McIntyre C, McLaren T, Meszaros E, Missong A, Mooshammer M, Negron CP, Nelson LA, Pfahler V, Poblete-Grant P, Randall M, Seguel A, Seth K, Smith AC, Smits MM, Sobarzo JA, Spohn M, Tawaraya K, Tibbett M, Voroney P, Wallander H, Wang L, Wasaki J, Haygarth PM (2018) Organic phosphorus in the terrestrial environment: a perspective on the state of the art and future priorities. Plant Soil 427:191-208

9. Gerke J, Romer W, Jungk A (1994) The excretion of citric and malic-acid by proteoid roots of Lupinus albus L. effects on soil solution concentrations of phosphate, iron, and aluminum in the proteoid rhizosphere in samples of an oxisol and a luvisol. Z Pflanzenernaehr Bodenkd 157:289-294

10. Giaveno C, Celi L, Richardson AE, Simpson RJ, Barberis E (2010) Interaction of phytases with soil minerals and availability of substrate affects the hydrolysis of inositol phosphates. Soil Biol Biochem 42:491-498

11. Giles CD, George TS, Brown LK, Mezeli MM, Richardson AE, Shand CA, Wendler R, Darch T, Menezes-Blackburn D, Cooper P, Stutter MI, Lumsdon DG, Blackwell NSA, Wearing C , Zhang H, Haygarth PM (2016) Does the combination of citrate and phytase exudation in Nicotiana tabacum promote the acquisition of endogenous soil organic phosphorus? Plant Soil 412:43-59

12. Giles CD, Richardson AE, Cade-Menun BJ, Mezeli MM, Brown LK, Menezes-Blackburn D, Darch T, Blackwell MSA, Shand CA, Stutter MI, Wendler R, Cooper P, Lumsdon DG, Wearing C, Zhang H, Haygarth PM, George TS (2018) Complementarity between citrate- and phytase-exuding Nicotiana tabacum plants depends on soil phosphorus availability and root intermingling. Physiologia Plant 163:356-371

13. Hayes JE, Richardson AE, Simpson RJ (2000) Components of organic phosphorus in soil extracts that are hydrolysed by phytase and acid phosphatase. Biol Fert Soils 32:279-286

14. Hong JK, Yamane I (1981) Distribution of inositol phosphate in the molecular size fractions of humic and fulvic acid fractions. Soil Sci Plant Nutr 27:295-303

15. Irving GCJ, McLaughlin MJ (1990) A rapid and simple field test for phosphorus in Olsen and Bray No. 1 extracts of soil. Comm Soil Sci Plant Anal 21:2245-2255

Page 19/25 
16. Isbell RF (1996) The Australian soil classification. CSIRO Publishing, Melbourne

17. Jackman R H and Black C A 1951 Solubility of iron, aluminum, calcium and magnesium inositol phosphates at different $\mathrm{pH}$ values. Soil Sci. 72, 179-186

18. Jarosch KA, Kandeler E, Frossard E, Bünemann EK (2019) Is the enzymatic hydrolysis of soil organic phosphorus compounds limited by enzyme or substrate availability? Soil Biol Biochem 139:107628

19. Jones DL (1998) Organic acids in the rhizosphere-a critical review. Plant Soil 205:25-44

20. Khademi Z, Jones DL, Malakouti MJ, Asadi F, Ardebili M (2009) Organic acid mediated nutrient extraction efficiency in three calcareous soils. Aust J Soil Res 47:213-220

21. Kidd D R, Ryan MH, Hahne D, Haling RE, Lambers H, Sandral GA, Simpson RJ, Cawthray GR (2018) The carboxylate composition of rhizosheath and root exudates from twelve species of grassland and crop legumes with special reference to the occurrence of citramalate. Plant Soil 424:389-403

22. Lambers H, Clements JC, Nelson MN (2013) How a phosphorus acquisition strategy based on carboxylate exudation powers the success and agronomic potential of lupines (Lupinus, Fabaceae). Amer J Bot 100:263-288.

23. Lambers H, Finnegan PM, Laliberte E, Pearse SJ, Ryan MH, Shane MW, Veneklaas EJ (2011) Phosphorus nutrition of Proteaceae in severely phosphorus-impoverished soils: are there lessons to be learned for future crops? Plant Physiol 156:1058-1066

24. Lambers H, Juniper D, Cawthray GR, Veneklaas EJ, Martinez-Ferri E (2002) The pattern of carboxylate exudation in Banksia grandis (Proteaceae) is affected by the form of phosphate added to the soil. Plant Soil 238:111-122

25. Lambers H, Martinoia E, Renton M (2015) Plant adaptations to severely phosphorus-impoverished soils. Curr Opin Plant Biology 25:23- 31

26. Lambers H, Raven JA, Shaver GR Smith SE (2008) Plant nutrient-acquisition strategies change with soil age. Trends Ecol Evol 23:95-103

27. Lynch JP, Brown KM (2001) Topsoil foraging - an architectural adaptation of plants to low phosphorus availability. Plant Soil 237:225-237

28. Martin M, Celi L, Barberis E (2004) Desorption and plant availability of myo-inositol hexaphosphate adsorbed on goethite. Soil Sci 169:115-124

29. Maruyama H, Yamamura T, Kaneko Y, Matsui H, Watanabe T, Shinano T, Osaki M, Wasaki J (2012) Effect of exogenous phosphatase and phytase activities on organic phosphate mobilization in soils with different phosphate adsorption capacities. Soil Sci Plant Nutri 58:41-51

30. Mclvor JG, 1 Guppy C, 2 Probert ME (2011) Phosphorus requirements of tropical grazing systems: the northern Australian experience. Plant Soil 349:55-67

31. McLaren TI, Smernik RJ, McLaughlin MJ, Doolette AL, Richardson AE, Frossard E (2019a) The chemical nature of soil organic phosphorus - a critical review and global compilation of quantitative data. Advan Agron 160:51-124

32. McLaren TI, Verel R, Frossard E (2019b) The structural composition of soil phosphomonoesters as determined by solution 31P NMR spectroscopy and transverse (T2) relaxation experiments. Geoderma 345:31-37

33. McLaughlin MJ, McBeath TM, Smernik R, Stacey SP, Ajiboye B, Guppy C (2011) The chemical nature of P accumulation in agricultural soils-implications for fertiliser management and design: an Australian perspective. Plant Soil 349:67-87

34. Neumann G, Massonneau A, Martinoia E, Romheld V (1999) Physiological adaptations to phosphorus deficiency during proteoid root development in white lupin. Planta 208:373-382

35. Nuruzzaman M, Lambers H, Bolland MDA, Veneklaas EJ (2006) Distribution of carboxylates and acid phosphatase and depletion of different phosphorus fractions in the rhizosphere of a cereal and three grain legumes. Plant Soil

Page 20/25 
281:109-120

36. Olsen SR, Cole CV, Watanabe FS, Dean LA (1954) Estimation of available phosphorus in soils by extraction with sodium bicarbonate. US Department of Agriculture Circular No. 939

37. Olsen SR, Sommers LE (1982) Phosphorus. In: Page AL, Miller RH, Keeney DR (eds) Methods of soil analysis, part 2. Chemical and microbiological properties, vol 2. ASA-SSSA, Madison, pp 403-430

38. Otani T, Ae N (1999) Extraction of organic phosphorus in Andosols by various methods. Soil Sci Plant Nutrit 45:151-161

39. Pearse SJ, Veneklaas EJ, Cawthray GR, Bolland MDA, Lambers H (2007) Carboxylate composition of root exudates does not relate consistently to a crop species ability to use phosphorus from aluminium, iron or calcium phosphate sources. New Phytol 173:181-190

40. Pearse SJ, Veneklaas EJ, Cawthray GR, Bolland MDA, Lambers H (2006) Carboxylate release of wheat, canola and 11 grain legume species as affected by phosphorus status. Plant Soil 288:127-139

41. Rayment G E, Lyons DJ (2011) Soil chemical methods: Australasia, 3. CSIRO publishing

42. Richardson AE, George TS, Hens M, Simpson RJ (2005) Utilisation of soil organic phosphorus by higher plants. In Turner BL, Frossard E, D. Baldwin D (eds) Organic Phosphorus in the Environment, CABI Publishing, Wallingford, UK, pp165-184

43. Richardson AE, Lynch JP, Ryan PR, Delhaize E, Smith FA, Smith SE, Harvey PR, Ryan MH, Veneklaas EJ, Lambers H, Oberson A, Culvenor RA, Simpson RJ (2011a) Plant and microbial strategies to improve the phosphorus efficiency of agriculture. Plant Soil 349:121-156

44. Richardson AE, Simpson RJ (2011b) Soil microorganisms mediating phosphorus availability. Plant Physiol 156:989-996

45. Richardson AE, Simpson RJ, George TS, Hocking PJ (2009). Plant mechanisms to optimize access to soil phosphorus. Crop Pasture Sci 60:124-143.

46. Roelofs RFR, Rengel Z, Cawthray GR, Dixon KW, Lambers H (2001) Exudation of carboxylates in Australian Proteaceae: chemical composition. Plant Cell Environ 24:891-903

47. Ryan PR, James RA, Weligama K, Delhaize E, Rattey A, Lewis DC, Bovill WD, McDonald G, Rathjen TM, Wang E, Fettell NA, Richardson AE (2014) Can citrate efflux from roots improve phosphorus uptake by plants? Testing the hypothesis with near-isogenic lines of wheat. Physiologia Plantarum 151:230-242

48. Schoenau JJ, Huang WZ (1991) Anion-exchange membrane, water, and sodium bicarbonate extractions as soil tests for phosphorus. Commun Soil Sci Plant Anal 22:465-492

49. Shane MW, Lambers H, Cawthray GR, Kuhn AJ, Schurr U (2008) Impact of phosphorus mineral source (Al-P or Fe-P) and $\mathrm{pH}$ on cluster-root formation and carboxylate exudation in Lupinus albus L. Plant Soil 304:169-178

50. Simpson RJ, Oberson A, Culvenor RA, Ryan MH, Veneklaas EJ, Lambers H, Lynch JP, Ryan PR, Delhaize E, Smith FA, Smith SE, Harvey PR, Richardson AE (2011) Strategies and agronomic interventions to improve the phosphorus-use efficiency of temperate farming systems. Plant Soil 349:89-120

51. Tadano T, Ozawa K, Sakai H, Osaki M, Matsui H (1993) Secretion of acid phosphatase by the roots of crop plants under phosphorus-deficient conditions and some properties of the enzyme. Plant Soil 155:95-98

52. Tang J, Leung A, Leung C, Lim BL (2006) Hydrolysis of precipitated phytate by three distinct families of phytases. Soil Biol Biochem 38:1316-1324

53. Turner BL (2007) Inositol phosphates in soil: amounts, forms and significance of the phosphorylated inositol stereoisomers. In Turner BL, Richardson AE, Mullaney EJ (eds) Inositol Phosphates: Linking Agriculture and the Environment, CAB International, Wallingford, UK, pp 186-206 
54. Turner BL (2008) Resource partitioning for soil phosphorus: a hypothesis. J Ecol 96:698-702

55. Turner BL, Brenes-Arguedas T, Condit R (2018) Pervasive phosphorus limitation of tree species but not communities in tropical forest. Nature 555:367-370.

56. Turner BL, Mahieu N, Condron LM (2003) Phosphorus-31 nuclear magnetic resonance spectral assignments of phosphorus compounds in soil NaOH-EDTA extracts. Soil Sci Soc Amer J 67:497-510

57. Turner BL, Papházy MJ, Haygarth PM, McKelvie ID (2002) Inositol phosphates in the environment. Philos Trans Roy Soc Series B 357:449-469

58. Turner BL, Richardson AE (2004) Identification of scyllo-inositol phosphates in soils by solution phosphorus-31 nuclear magnetic resonance spectroscopy. Soil Sci Soc Amer J 68:802-808

59. Veneklaas E J, Stevens J, Cawthray GR, Turner S, Grigg AM, Lambers H (2003) Chickpea and white lupin rhizosphere carboxylates vary with soil properties and enhance phosphorus uptake. Plant Soil 248:187-197

60. Wang X, Pearse SJ, Lambers H (2013) Cluster-root formation and carboxylate release in three Lupinus species as dependent on phosphorus supply, internal phosphorus concentration and relative growth rate. Ann Bot 112:14491459

61. Wang Y, Lambers H (2020) Root-released organic anions in response to low phosphorus availability: recent progress, challenges and future perspectives. Plant Soil 447:135-156

62. Wassen MJ, Venterink HO, Lapshina ED, Tanneberger F (2005) Endangered plants persist under phosphorus limitation. Nature 437:547-550

63. Weaver DM, Wong MTF (2011) Scope to improve phosphorus (P) management and balance efficiency of crop and pasture soils with contrasting $P$ status and buffering indices. Plant Soil 349:37-54

64. Wei LL, Chen CR, Xu ZH (2010) Citric acid enhances the mobilization of organic phosphorus in subtropical and tropical forest soils. Biol Fert Soils 46:765-769

65. Weisskopf L, Abou-Mansour E, Fromin N, Tomasi N, Santelia D, Edelkott I, Neumann G, Aragno M, Tabacchi R, Martinoia E (2006) White lupin has developed a complex strategy to limit microbial degradation of secreted citrate required for phosphate acquisition. Plant Cell Environ 29:919-927

66. Wouterlood M, Cawthray GR, Turner S, Lambers H, Veneklaas EJ (2004) Rhizosphere carboxylate concentrations of chickpea are affected by genotype and soil type. Plant Soil 261:1-10

67. Zemunik G, Turner BL, Lambers H, Laliberte E (2015) Diversity of plant nutrient-acquisition strategies increases during long-term ecosystem development. Nature Plants 1:1-4

\section{Figures}




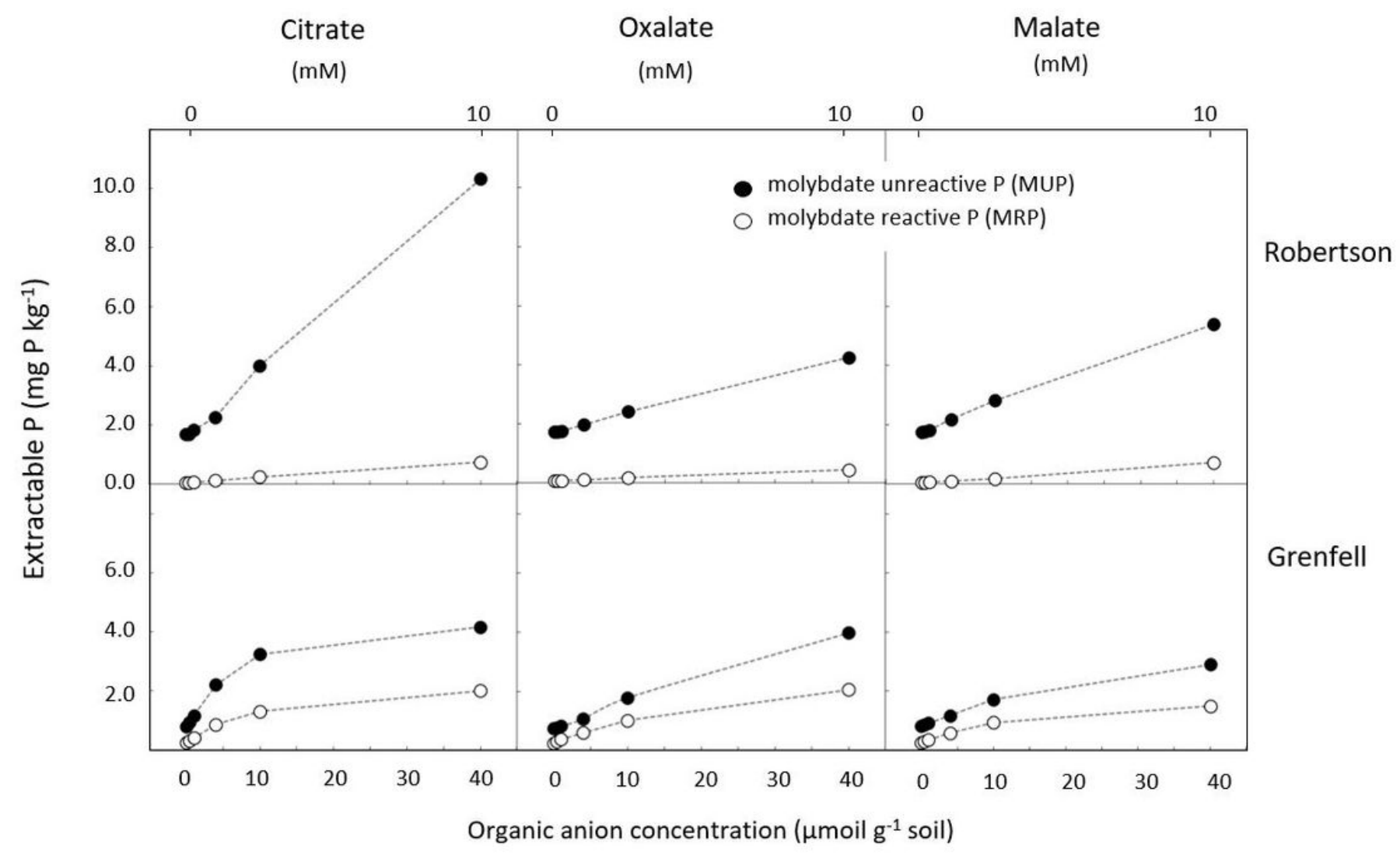

Figure 1

Organic anion extraction of phosphorus $(P)$ from the Robertson and Grenfell soils. Shown are the concentrations (mg $P$ $\mathrm{kg}^{-1}$ soil) of molybdate-reactive P (MRP) and molybdate-unreactive P (MUP) extracted by water (zero value) and by citrate, oxalate, and malate each at 5 concentrations. Each data point is the mean of 3 replicates $(n=3)$ with an average coefficient of variation (standard deviation/mean) of $2.9 \%$ (range 0.1 to $6.9 \%$ ) across all of the means. 


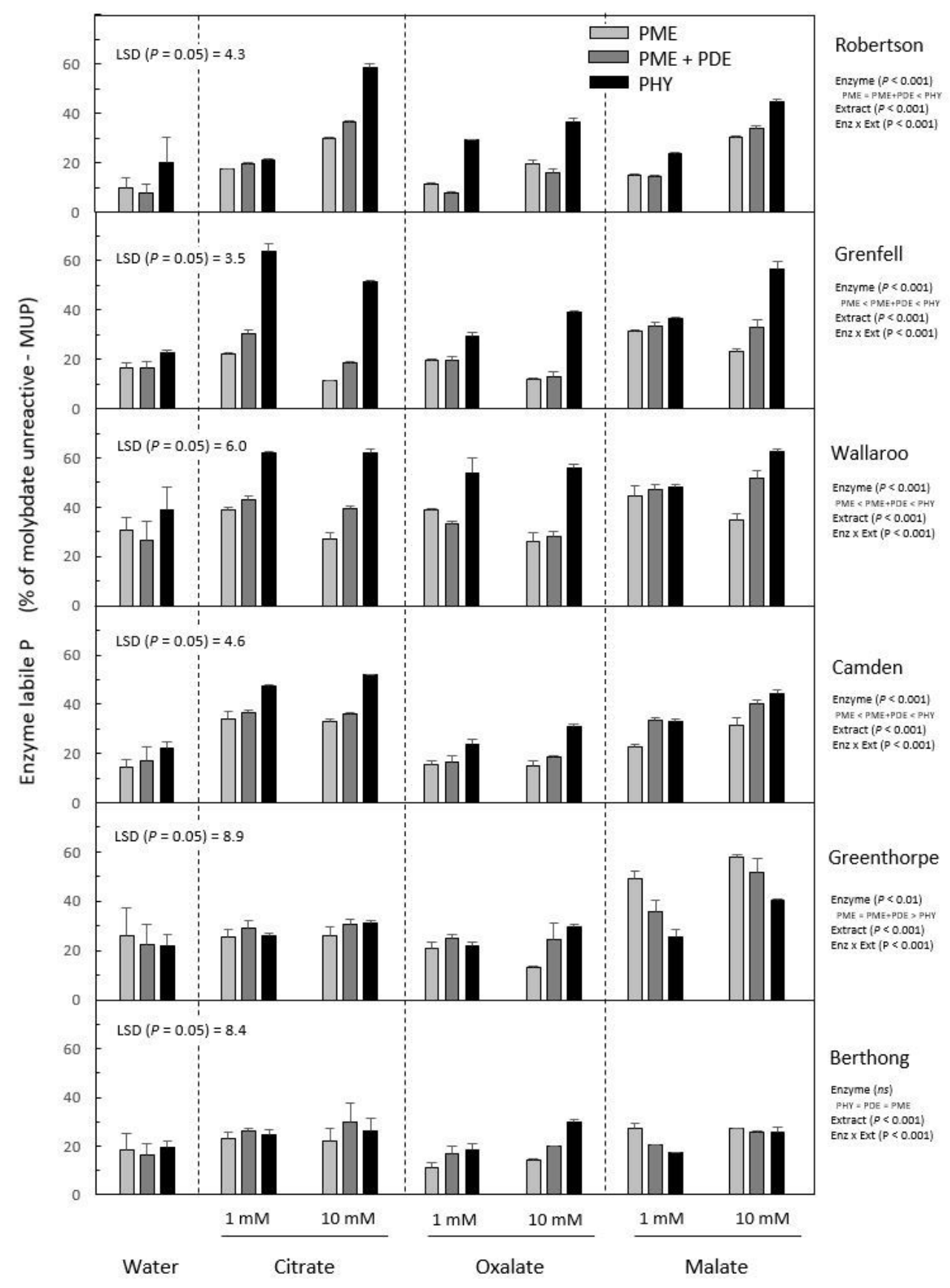

Figure 2

Enzyme labile phosphorus (P) following extraction of soil with organic anions and incubation with phosphatases. Shown is the percentage (\%) of that total molybdate unreactive P (MUP) that was hydrolysed to molybdate reactive (MRP) after incubation of soil extracts with phosphomonoesterase (PME), PME in combination with phosphodiesterase $(\mathrm{PME}+\mathrm{PDE})$, or with phytase (PHY). Soils were extracted by water and by citrate, oxalate, and malate each at two concentrations ( 1 and $10 \mathrm{mM})$. Values are the mean of 3 replicates $(n=3)$ and bars on each column (where shown) show 1 standard deviation. For each soil the significance of Enzyme and Extract (as main effects) and the Enzyme $x$ Extract (interaction) is shown with indication of the least significant difference (LSD) value for the Enzyme $x$ Extract interaction $(P=0.05)$ shown for each soil. 
Robertson

(Ferrosol)
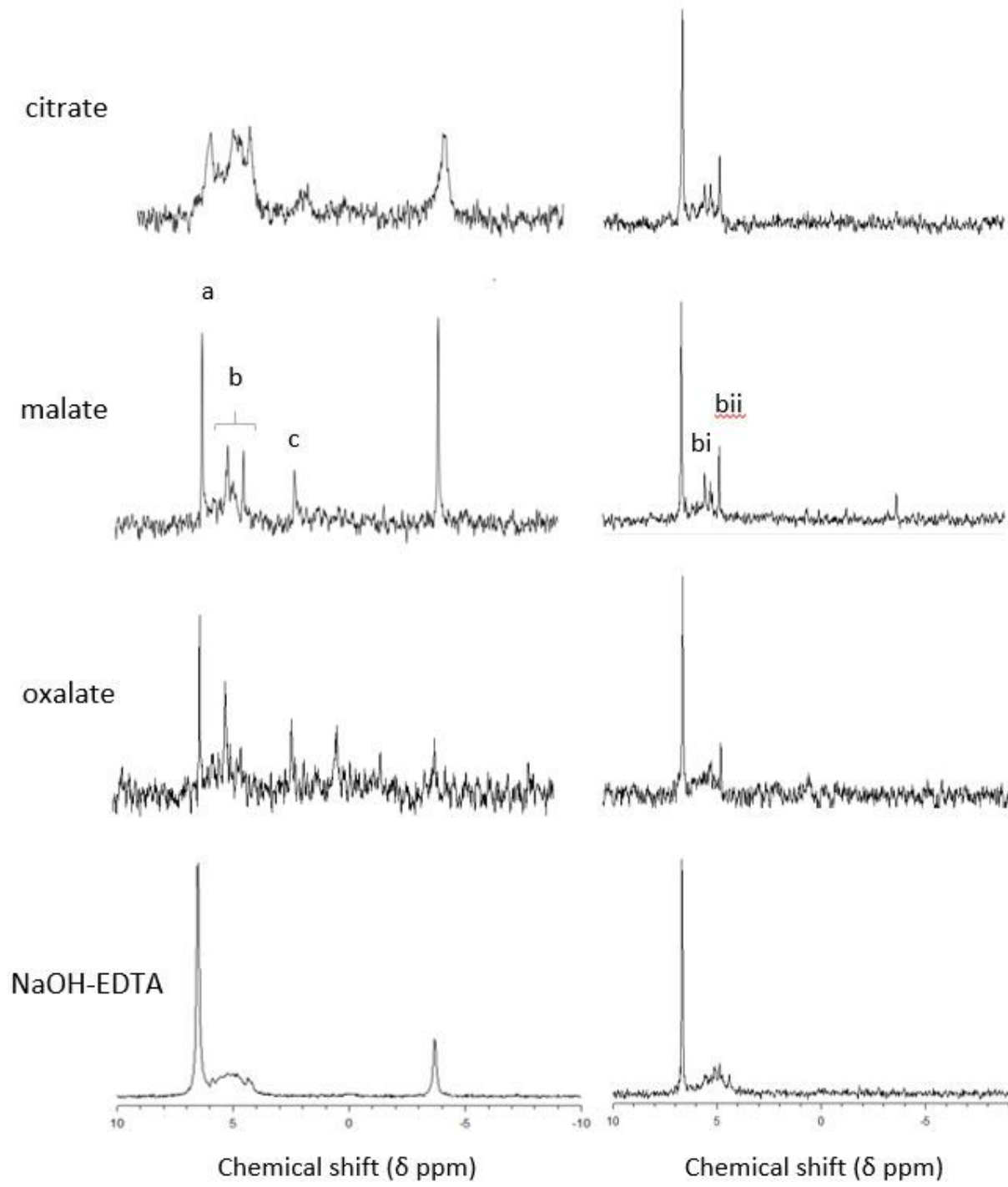

Grenfell

(Kandosol)
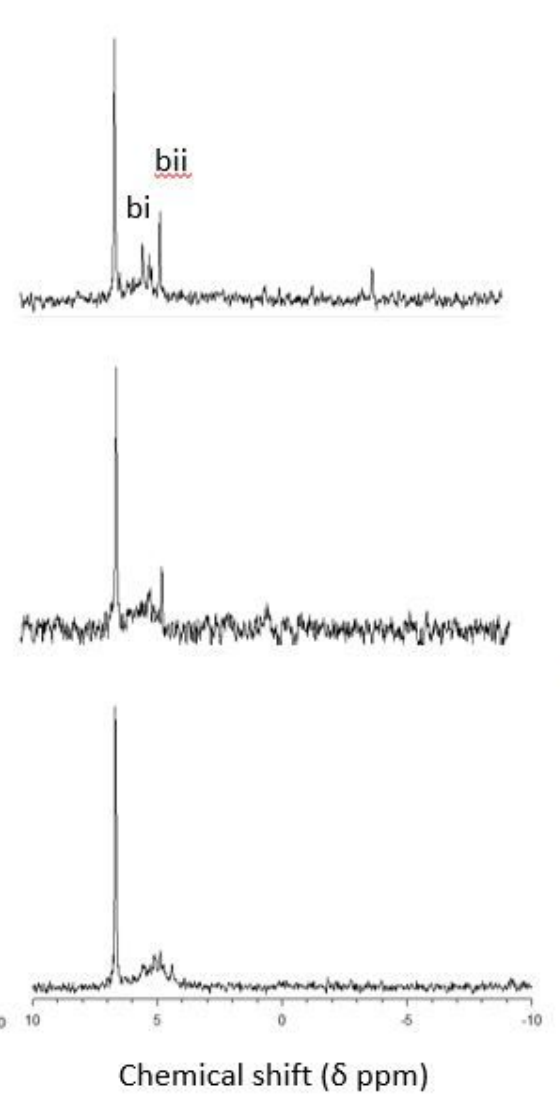

Camden

(Vertosol)
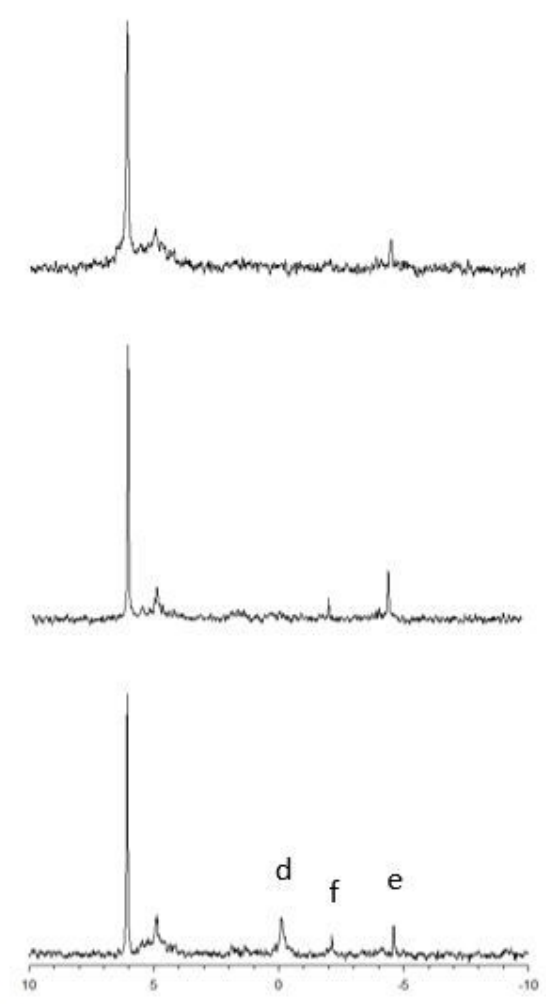

Chemical shift ( $\delta$ ppm)

\section{Figure 3}

Solution ${ }^{31}$ P NMR spectra for extracts from the Robertson, Grenfell and Camden soils. The soils were extracted with $10 \mathrm{mM}$ solutions of organic anions (citrate, malate, oxalate) and, for the Robertson and Grenfell soils, NaOH-EDTA. Identifiable peaks were assigned to major classes of $\mathrm{P}$ according to spectral shifts based on NaOH-EDTA spectra, and are indicated as (a) orthophosphate, (b) phosphomonoesters (bi and bii, potentially as myo- and scyllo-inositol hexakisphosphate, respectively), (c) phospholipids, (d) DNA, (e) pyrophosphate and (f) as other (a non-identifiable potential diester). 